\title{
Fate of macroalgae in benthic systems: carbon and nitrogen cycling within the microbial community
}

\author{
Amber K. Hardison ${ }^{1,3, *}$, Elizabeth A. Canuel ${ }^{1}$, Iris C. Anderson ${ }^{1}$, Bart Veuger ${ }^{2}$ \\ ${ }^{1}$ Virginia Institute of Marine Science, College of William and Mary, PO Box 1346, Gloucester Point, Virginia 23062, USA \\ ${ }^{2}$ Netherlands Institute of Ecology, Center for Estuarine and Marine Ecology, PO Box 140, 4400 AC Yerseke, The Netherlands
}

${ }^{3}$ Present address: Brown University, 80 Waterman Street G-W101, Providence, Rhode Island 02912, USA

\begin{abstract}
High nutrient loading to coastal bays is often accompanied by the presence of bloomforming macroalgae, which take up and sequester large amounts of $\mathrm{C}$ and $\mathrm{N}$ while growing. This pool is temporary, however, as nuisance macroalgae exhibit a bloom and die-off cycle, influencing the biogeochemical functioning of these systems in unknown ways. The objective of this study was to trace the $\mathrm{C}$ and $\mathrm{N}$ from senescing macroalgae into relevant sediment pools. A macroalgal die-off event was simulated by the addition of freeze-dried macroalgae (Gracilaria spp.), pre-labeled with stable isotopes $\left({ }^{13} \mathrm{C}\right.$ and $\left.{ }^{15} \mathrm{~N}\right)$, to sediment mesocosms. The isotopes were traced into bulk sediments and partitioned into benthic microalgal (BMA) and bacterial biomass using microbial biomarkers to quantify the uptake and retention of macroalgal $\mathrm{C}$ and $\mathrm{N}$. Bulk sediments took up label immediately following the die-off, and macroalgal $\mathrm{C}$ and $\mathrm{N}$ were retained in the sediments for at least $2 \mathrm{wk}$. Approximately 6 to $50 \%$ and 2 to $9 \%$ of macroalgal $\mathrm{N}$ and C, respectively, were incorporated into the sediments. Label from the macroalgae appeared in both bacterial and BMA biomarkers, suggesting that efficient shuttling of macroalgal $\mathrm{C}$ and $\mathrm{N}$ between these communities may serve as a mechanism for retention of macroalgal nutrients within the sediments.
\end{abstract}

KEY WORDS: Stable isotopes $\cdot$ Macroalgae $\cdot$ Benthic microalgae $\cdot$ Bacteria $\cdot$ Biomarker $\cdot$ Coastal eutrophication Resale or republication not permitted without written consent of the publisher

\section{INTRODUCTION}

Macroalgal blooms are increasingly recognized as a symptom of eutrophication in shallow coastal systems worldwide (Duarte 1995, Valiela et al. 1997). Their proliferation has been linked to increased nutrient loadings (Hauxwell et al. 2001, Bintz et al. 2003), and in many systems macroalgae have replaced slower-growing seagrasses and perennial macrophytes (Duarte 1995, Valiela et al. 1997, Hauxwell et al. 2001, Bintz et al. 2003, McGlathery et al. 2007). In temperate systems blooms usually develop in spring and collapse in mid to late summer, when high temperatures and selfshading negatively affect algal productivity (Peckol \& Rivers 1995, McGlathery et al. 1997, Brush \& Nixon 2003, Higgins et al. 2008). The deleterious effects these blooms have on the surrounding system while alive and following die-off have been studied extensively (e.g. Sfriso et al. 1992, Raffaelli 2000, Hauxwell et al. 2001, Cummins et al. 2004, Nuzzi \& Waters 2004).

Blooms can attain biomasses up to $10 \mathrm{~kg}$ wet weight $\mathrm{m}^{-2}$ (Gordon \& McComb 1989, Pavoni et al. 1992, Valiela et al. 1992, Morand \& Briand 1996, Astill \& Lavery 2001). While growing, macroalgae take up and sequester significant quantities of nutrients, often at similar magnitudes to nutrient loading, thereby serving effectively as a nutrient filter (Thybo-Christesen et al. 1993, Valiela et al. 1997, McGlathery et al. 1996, 2001, Pedersen et al. 2004). However, these blooms are not long-lived and, therefore, do not serve as a permanent nutrient reservoir. Although the fate of senescent macroalgal biomass is not fully known, it likely greatly impacts nutrient cycling dynamics within these systems. 
Studies of macroalgal bloom decay have demonstrated rapid breakdown of biomass, resulting in release of both inorganic and organic nutrients to the water column (Buchsbaum et al. 1991, Tyler et al. 2001, Castaldelli et al. 2003, García-Robledo et al. 2008), supporting phytoplankton and bacterial metabolism (Sfriso et al. 1992, Nedergaard et al. 2002). Fewer studies have focused on macroalgal decay within the sediments (Nedergaard et al. 2002, Lomstein et al. 2006, Rossi 2007, GarcíaRobledo et al. 2008), where heterotrophic bacterial densities are significantly higher than in the water column (Deming \& Baross 1993, Schmidt et al. 1998, Ducklow 2000). In addition, most of the sediment studies have been conducted in low or no light environments, even though light is typically available to shallow sediments where macroalgal die-offs occur and sediment biogeochemistry is largely affected by benthic microalgal (BMA) activity (Underwood \& Kromkamp 1999). While nutrients associated with senescent macroalgal blooms are recycled and can have a positive feedback on phytoplankton production in the water column, nutrients released during macroalgal decay in the sediments may support BMA and bacterial production, which could intercept the return of nutrients to the overlying water column. Thus if shallow-water sediments behave as a nutrient filter, the response by phytoplankton may be reduced, and benthic production could effectively buffer the system from further eutrophication. In order to better constrain the input and retention of macroalgae-associated nutrients in the sediments, we used a dual stable isotope labeling approach to track macroalgal $\mathrm{C}$ and $\mathrm{N}$ into bulk sediments and the sediment microbial community after a simulated macroalgal die-off.

\section{MATERIALS AND METHODS}

Site description. Sediments and macroalgae were collected from 2 lagoons along the Delmarva Peninsula, USA: Hog Island Bay, Virginia (HIB) and Isle of Wight Bay, Maryland (IWB; Fig. 1). These bays are typical of temperate lagoons along the US East Coast. Both are shallow, on average less than $2 \mathrm{~m}$ deep at mean low water, and are characterized by ephemeral macroalgal blooms (Goshorn et al. 2001, McGlathery

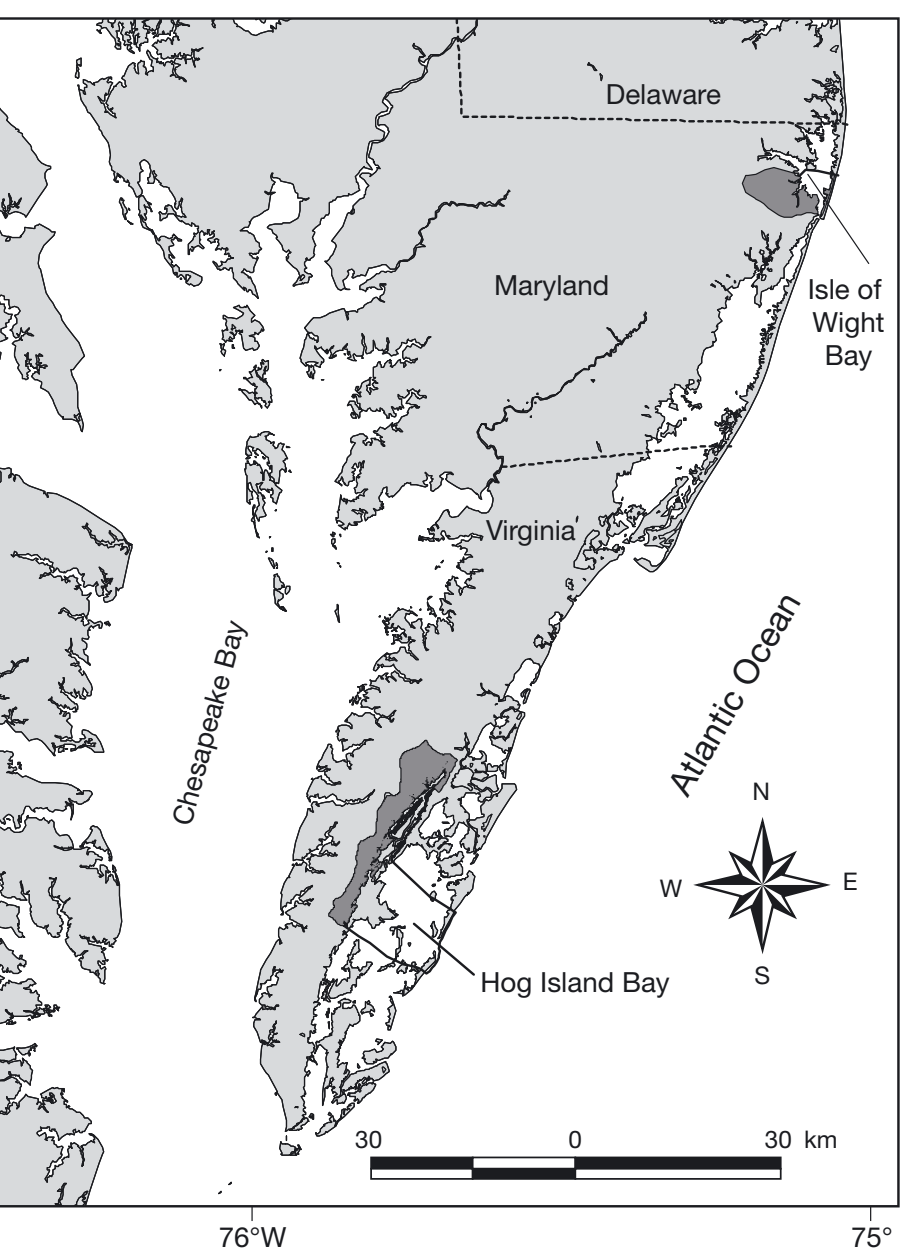

Fig. 1. Sediments and macroalgae were collected from 2 coastal lagoons: Hog Island Bay, VA, and Isle of Wight Bay, MD. Dark grey shaded areas indicate the watersheds of each lagoon. Hog Island Bay is located within the Virginia Coast Reserve LTER network

et al. 2001, Thomsen et al. 2006); however, there are important differences between the lagoons. External loading of nutrients (nitrogen) to HIB (14 kg N ha ${ }^{-1}$ $\mathrm{yr}^{-1}$; Anderson et al. 2010) is lower than for IWB (65 kg $\mathrm{N}$ ha $^{-1} \mathrm{yr}^{-1}$; Boynton et al. 1996), and as a result, macroalgal densities in HIB are lower and only dominant at select sites during brief portions of the year (Boynton et al. 1996, Goshorn et al. 2001, McGlathery et al. 2001, Stanhope et al. 2009, present study).

Experimental design. A flow-through mesocosm array was set up at the Virginia Institute of Marine Science (VIMS) Eastern Shore Laboratory (ESL) in Wachapreague, VA. Each mesocosm $(0.61 \times 0.61 \mathrm{~m}$, diameter $\times$ height) was constructed of translucent fiberglass to allow maximum light penetration (87\% visual light transmission; Solar Components). Three mesocosms were filled with sediments from one location in each lagoon in June 2006 to a depth of $\sim 20 \mathrm{~cm}$ using intact sediments extruded from cores taken at 
the field sites. The field sites were chosen based on the presence of macroalgal blooms in previous monitoring efforts. Care was taken not to include any macroalgae or visible macrofauna in the collected cores. At the ESL, the mesocosms were placed in shallow water baths under $30 \%$ shade cloth to control temperature and light. Ambient, filtered $(10 \mu \mathrm{m})$ seawater, pumped from the creek adjacent to the ESL, was delivered gravimetrically to each mesocosm at a rate that achieved a water column flushing time of $\sim 2 \mathrm{~d}$, similar to the flushing time observed at the study sites (Oertel 2001). The water column was circulated using mini-jet pumps (Aquatic Ecosystems, Inc.) secured on the inner tank wall $\sim 18 \mathrm{~cm}$ above the sediment surface to avoid sediment resuspension. The mesocosms were equilibrated for 2 wk before beginning the experiment. Water column temperature and salinity were measured in each mesocosm throughout the experiment using a YSI datasonde.

Macroalgae (Gracilaria spp.) were collected from both lagoons in May 2006 and returned to the laboratory for isotopic labeling. The macroalgae were cleaned of epiphytes and epifauna, rinsed with $0.7 \mu \mathrm{m}$ filtered seawater, and placed in separate aquaria inside a greenhouse. Filtered $(0.7 \mu \mathrm{m})$ seawater was added to each tank and aerated during labeling. The algae were starved for $10 \mathrm{~d}$ and then fertilized daily for $14 \mathrm{~d}$ with a solution containing 50 atom \% (at.\%) ${ }^{15} \mathrm{~N}^{-\mathrm{NH}_{4}}{ }^{+}$(as $\mathrm{NH}_{4} \mathrm{Cl}$ ) and 98 at. $\%{ }^{13} \mathrm{C}-\mathrm{HCO}_{3}{ }^{-}$(as $\mathrm{NaHCO}_{3}$ ). Rates of $\mathrm{N}$ and $\mathrm{C}$ addition were estimated to sustain tissue $\mathrm{N}$ at $3 \%$ and $\mathrm{C}$ at $25 \%$ of dry weight (DW) with a growth rate of $5 \% \mathrm{~d}^{-1}$ following the procedure of Tyler \& McGlathery (2006). To insure that $\mathrm{P}$ was not limiting, $\mathrm{P}$ was added to provide a 10:1 ratio of N:P. At the end of the labeling period, the algae were rinsed with filtered $(0.7 \mu \mathrm{m})$ seawater, patted dry, and freeze-dried as intact tissues. The final isotopic enrichments of the dead macroalgae were approximately 30 at. \% ${ }^{15} \mathrm{~N}$ and 9 at. $\%{ }^{13} \mathrm{C}$. After the mesocosm equilibration period, the intact, isotopically labeled, freeze-dried algal tissues were added to the surface of sediments in corresponding mesocosms from HIB or IWB, at ambient densities observed in each system (HIB: $84 \mathrm{~g} \mathrm{DW} \mathrm{m}^{-2}$; IWB: $184 \mathrm{~g} \mathrm{DW} \mathrm{m}{ }^{-2}$; Table 1). The intact macroalgae settled to the sediment surface, but retained some buoyancy for the first $2 \mathrm{~d}$ due to the gentle water circulation; after $1 \mathrm{wk}$, macroalgae were no longer visible.

Sediment sampling. The mesocosms were sampled $1 \mathrm{~d}$ prior to the macroalgal additions to capture baseline conditions (Day 0) and on Days 1, 2, 7, and 14 after the additions. At each sampling, surface sediments ( 0 to $1 \mathrm{~cm})$, collected using 2 acrylic cores $(5.7 \mathrm{~cm}$ i.d.), were reserved for bulk (total organic $\mathrm{C}$ [TOC], total $\mathrm{N}$ [TN]), amino acid, and fatty acid analyses. Sediments from both cores were combined in pre-combusted glass jars, immediately frozen at $-4^{\circ} \mathrm{C}$, and frozen at $-80^{\circ} \mathrm{C}$ within $3 \mathrm{~d}$. The remaining sediment in the cores was placed carefully back into the holes in the mesocosm sediments. Surface sediments from a third acrylic core were collected and processed immediately for determination of bulk density, organic content, and water content. Sediments were also collected for chlorophyll a ( $\mathrm{chl} \mathrm{a}$ ) concentrations using a cut-off syringe $(1.1 \mathrm{~cm}$ i.d.). Samples were sectioned into 0 to $0.3 \mathrm{~cm}$ and 0.3 to $1.0 \mathrm{~cm}$ horizons, placed into $15 \mathrm{ml}$ centrifuge tubes, immediately frozen at $-4^{\circ} \mathrm{C}$, and analyzed within 1 mo. A different region of the sediment surface was sampled each time to avoid resampling any sediments.

Bulk sediment analyses. Sediments for percent water and organic matter (OM) were processed immediately. A known volume of sediment was weighed, dried at $40^{\circ} \mathrm{C}$ and reweighed for water content and bulk density. The dried sediments were combusted for $4 \mathrm{~h}$ at $500^{\circ} \mathrm{C}$ to obtain ash-free dry weight. Samples were analyzed for benthic chl a concentrations according to the method of Pinckney et al. (1994), a modification of Lorenzen (1967). The sediment pellet was sonicated in $90 \%$ acetone, vortexed, and extracted for $24 \mathrm{~h}$ at $-4^{\circ} \mathrm{C}$. The supernatant was passed through a $0.45 \mu \mathrm{m}$ filter and read on a Shimadzu UV-1601 UV visible spectrophotometer $(\lambda=665,750 \mathrm{~nm})$. Chl a concentrations $\left(\mathrm{mg} \mathrm{m}^{-2}\right)$ for the 0 to 0.3 and 0.3 to $1.0 \mathrm{~cm}$ horizons were calculated according to the equations in

Table 1. Environmental parameters measured in the field and in the mesocosms. Except for peak macroalgal biomass, field values were combined for 2 sampling dates in June 2006 at 3 sites in each lagoon $(n=6)$. Mesocosm values are presented as the mean $( \pm \mathrm{SE})$ across all 5 sampling days during the experiment $(\mathrm{n}=$ 15). Peak macroalgal biomass values for the field correspond to the maximum biomass measured from May through October 2006 at multiple sites across Hog Island Bay (HIB; $\mathrm{n}=9$ ) and Isle of Wight Bay (IWB: $\mathrm{n}=5$ ). Mesocosm values correspond to the mass of freeze-dried, labeled macroalgae added to each mesocosm $(n=3)$. n/a: not applicable

\begin{tabular}{|c|c|c|c|c|}
\hline \multirow[t]{2}{*}{ Parameter } & \multicolumn{2}{|c|}{ Field } & \multicolumn{2}{|c|}{ Mesocosm } \\
\hline & HIB & IWB & HIB & IWB \\
\hline Temperature $\left({ }^{\circ} \mathrm{C}\right)$ & $28.3(0.1)$ & $28.6(0.2)$ & $22.2(1.2)$ & $23.0(1.2)$ \\
\hline Salinity (psu) & $31.3(0.01)$ & $29.3(0.08)$ & $30.1(0.7)$ & $29.9(0.7)$ \\
\hline Sediment organic matter (\%) & $2.59(0.77)$ & $0.77(0.10)$ & $2.01(0.18)$ & $1.04(0.07)$ \\
\hline Chlorophyll a (mg chl a m${ }^{-2}$ ) & $56.2(14.5)$ & $89.5(19.7)$ & $26.7(3)$ & $109(7)$ \\
\hline \multicolumn{5}{|c|}{ Peak macroalgal biomass (g DW $\mathrm{m}^{-2}$ ) } \\
\hline Range & $0-192$ & $29-538$ & $\mathrm{n} / \mathrm{a}$ & $\mathrm{n} / \mathrm{a}$ \\
\hline Mean & $52(24)$ & $176(98)$ & $83(2)$ & $183(2)$ \\
\hline
\end{tabular}


Lorenzen (1967) and added to obtain the concentration for the 0 to $1 \mathrm{~cm}$ horizon.

For bulk sediment TOC, TN, and isotopic measurements, sediments were freeze-dried, ground and homogenized, acidified with $10 \% \mathrm{HCl}$ to remove inorganic C (Hedges \& Stern 1984), and analyzed for ${ }^{13} \mathrm{C} /{ }^{12} \mathrm{C}$ and ${ }^{15} \mathrm{~N} /{ }^{14} \mathrm{~N}$ using a PDZ Europa ANCA-GSL elemental analyzer interfaced to a PDZ Europa 20-20 isotope ratio mass spectrometer (EA-IRMS, Sercon) at the University of California at Davis Stable Isotope Facility. Stable isotope ratios for $\mathrm{C}\left(\mathrm{R}={ }^{13} \mathrm{C} /{ }^{12} \mathrm{C}\right)$ and $\mathrm{N}$ $\left(\mathrm{R}={ }^{15} \mathrm{~N} /{ }^{14} \mathrm{~N}\right)$ were used to calculate $\delta$-values in units of per mil (\%o):

$$
\delta X(\%)=\left[\left(\mathrm{R}_{\text {sample }} / \mathrm{R}_{\text {standard }}\right)-1\right] \times 1000
$$

where $X$ is ${ }^{13} \mathrm{C}$ or ${ }^{15} \mathrm{~N}$. Samples were expressed relative to international standards Pee Dee Belemnite (C) and atmospheric $\mathrm{N}_{2}$. $\delta X$ was used to calculate at.\% $X$, which was used to calculate excess $X$ (absolute amount of incorporated ${ }^{13} \mathrm{C}$ or ${ }^{15} \mathrm{~N}$ ):

$$
\text { at. } \% X=\left[\begin{array}{rl}
{\left[100 \times \mathrm{R}_{\text {standard }} \times\left(\delta X_{\text {sample }} / 1000+1\right)\right] /} \\
& {\left[1+6 \mathrm{R}_{\text {standard }} \times\left(\delta X_{\text {sample }} / 1000+1\right)\right]}
\end{array}\right.
$$

excess $X\left(\mathrm{nmol} X \mathrm{~g} \mathrm{DW}^{-1}\right)=\left[\left(\right.\right.$ at. $\% X_{\text {sample }}-$

$$
\text { at. } \left.\% X_{\text {control }} / 100\right] \times \text { concentration }_{\text {sample }}
$$

where concentrations were expressed in moles $\mathrm{C}$ or $\mathrm{N}$ relative to sediment dry weight. The control (unlabeled) samples were collected on Day 0, before macroalgae were added to the mesocosms.

Hydrolyzable amino acids. Hydrolyzable amino acids (HAAs) were extracted and analyzed according to the method presented in Veuger et al. (2005). Freeze-dried sediment ( $1 \mathrm{~g}$ ) was rinsed with $2 \mathrm{~N} \mathrm{HCl}$ and Milli-Q water to remove dissolved amino acids. The sediment pellet was then hydrolyzed with $6 \mathrm{~N} \mathrm{HCl}$ at $110^{\circ} \mathrm{C}$ for $20 \mathrm{~h}$. Following purification by cation exchange chromatography, amino acids were derivatized with isopropanol and pentafluoropropionic anhydride and further purified by solvent extraction. Concentrations and stable isotope ratios for $\mathrm{C}\left(\mathrm{R}={ }^{13} \mathrm{C} /{ }^{12} \mathrm{C}\right)$ and $\mathrm{N}\left(\mathrm{R}={ }^{15} \mathrm{~N} /{ }^{14} \mathrm{~N}\right)$ of the derivatized $\mathrm{D}$ - and L-amino acids were measured at the Netherlands Institute of Ecology (NIOO) by gas chromatography-combustionisotope ratio mass spectrometry (GC-C-IRMS) on an HP 6890 GC (Chirasil L-Val column) with a Thermo type III combustion interface and a Thermo Delta Plus IRMS. $\delta$-and at. $\% X$ values were calculated according to Eqs. (1) \& (2) and used to calculate excess $X$ according to Eq. (3), where amino acid concentrations were expressed in moles $\mathrm{C}$ or $\mathrm{N}$ relative to sediment dry weight. Carbon isotopic values of amino acids were corrected for the $\mathrm{C}$ atoms added during derivatization using a mass balance approach following Veuger et al.
(2006). The sum of concentrations of, and/or excess label incorporated in, all amino acids analyzed will be referred to as total HAAs (THAAs).

The ratio of excess ${ }^{13} \mathrm{C}$ or ${ }^{15} \mathrm{~N}$ incorporation into Dalanine (D-Ala), a bacterial-specific amino acid, relative to L-alanine (L-Ala), an amino acid made by all organisms, was calculated as:

D/L-Ala ratio $(\mathrm{D} / \mathrm{L}-\mathrm{Ala})=(\operatorname{excess} X$ in D-Ala $) /$

where $X$ was ${ }^{13} \mathrm{C}$ or ${ }^{15} \mathrm{~N}$. During hydrolysis, some racemization of L-Ala to $\mathrm{D}$-Ala takes place, resulting in a D/L-Ala value of $\sim 0.017$ (Veuger et al. 2007b). We corrected values of excess isotope in D-Ala for this racemization according to Veuger et al. (2007a), whereas values of D/L-Ala have been left uncorrected. Instead, the D/L-Ala value of 0.017 will be indicated graphically in our results to reflect racemization during hydrolysis (Veuger et al. 2007b). We estimated the bacterial contribution to total ${ }^{13} \mathrm{C}$ or ${ }^{15} \mathrm{~N}$ incorporation according to Veuger et al. (2007a):

Bacterial contribution $(\%)=[($ excess $X$ D/L-Ala $0.017) /($ bacterial D/L-Ala - 0.017)] $\times 100 \%$

where $X$ was ${ }^{13} \mathrm{C}$ or ${ }^{15} \mathrm{~N}$. Bacterial D/L-Ala represents the D/L-Ala abundance ratio for bacteria. The upper bound of the ratio ranges from 0.05 for Gram-negative ( $\mathrm{G}-$ ) bacteria, to 0.1 for Gram-positive $(\mathrm{G}+)$ bacteria and cyanobacteria (Veuger et al. 2007b). Previous work suggests that $\mathrm{G}+$ bacteria are more prominent in deeper (anaerobic) sediments (Moriarty \& Hayward 1982, Gontang et al. 2007). Since the present study used sandy photic sediments, we assumed that the contribution from $\mathrm{G}+$ bacteria was negligible. Additionally, photosynthetic pigment analyses obtained by HPLC of sediments from the HIB field sites showed low zeaxanthin:chlorophyll ratios, suggesting that cyanobacterial contribution to the microbial community was negligible (M. Waters pers. comm.). As a result, we further assumed that their contribution to the D/L-Ala ratio of the total microbial community was negligible, and we estimated the bacterial D/L-Ala ratio for our sediments at 0.05 . This will also be indicated graphically in our results. The lower bound of D/L-Ala, when bacteria do not take up any label, is 0.017 , which represents abiotic racemization of L-Ala (Veuger et al. 2007b). Thus excess ${ }^{13} \mathrm{C}$ and ${ }^{15} \mathrm{~N}$ D/L-Ala ratio values should fall between these upper and lower limits, with higher values indicating a higher bacterial contribution to the total label uptake since only bacteria incorporate label into D-Ala.

Phospholipid-linked fatty acids. Total fatty acids were analyzed according to a modified Bligh \& Dyer (1959) method (Poerschmann \& Carlson 2006, Canuel 
et al. 2007). Wet sediments ( 12 g) were extracted using an accelerated solvent extractor (ASE) system (Dionex ASE 200) adapted for in-cell silica gel chromatography. Each sample was extracted twice on the ASE: neutral lipids were collected following extraction with a 9:1 (v:v) hexane:acetone mixture at $50^{\circ} \mathrm{C}$, and then polar lipids were collected following extraction with a 8:2 (v:v) methanol:chloroform solution at $80^{\circ} \mathrm{C}$. Neutral and polar lipid fractions were saponified using $\mathrm{KOH}-\mathrm{CH}_{3} \mathrm{OH}$ for $2 \mathrm{~h}$ at $110^{\circ} \mathrm{C}$. Saponified samples were then extracted under basic and acidic conditions. The acid-extracted fractions were methylated with $\mathrm{BF}_{3}-\mathrm{CH}_{3} \mathrm{OH}$ to form fatty acid methyl esters (FAMEs). The neutral FAMEs included neutral and glycolipids, while the polar FAMEs represented the phospholipidlinked fatty acids (PLFAs). FAME concentrations were measured by gas chromatography with flame ionization detection (GC-FID; DB-5 column, HP 5890) and quantified using methyl heneicosanoate as an internal standard. Peak identities were verified using reference standards as well as coupled gas chromatography mass spectrometry (GC-MSD; HP 6890). Fatty acids are designated $\mathrm{A}: \mathrm{B} \omega \mathrm{C}$, where $\mathrm{A}$ is the total number of carbon atoms, $\mathrm{B}$ is the number of double bonds, and $\mathrm{C}$ is the position of the first double bond from the aliphatic ' $\omega$ ' end of the molecule. The prefixes ' $i$ ' and 'a' refer to iso- and anteiso-methyl branched fatty acids, respectively (see Canuel et al. 1995 and references therein). Stable $C$ isotope ratios $\left(R={ }^{13} \mathrm{C} /{ }^{12} \mathrm{C}\right)$ for PLFAs were measured at NIOO with a GC-C-IRMS system consisting of a Trace GC Ultra gas chromatograph (BPX70 column) coupled to a Delta Plus Advantage IRMS through a GC/C-III interface and were used to calculate $\delta^{13} \mathrm{C}$ (Eq. 1) and at. $\%{ }^{13} \mathrm{C}$ (Eq. 2). Excess ${ }^{13} \mathrm{C}$ was calculated according to Eq. (3), where concentrations were FAME concentrations expressed in moles $\mathrm{C}$ relative to dry weight. Actual PLFA isotopic values were derived from the FAME isotopic compositions by correcting for the isotopic composition of the $\mathrm{C}$ added during derivatization using a mass balance approach. We analyzed the concentrations and isotopic content of total PLFAs as well as branched odd fatty acids (BrFAs; summed excess ${ }^{13} \mathrm{C}$ in iso- and anteiso- $\mathrm{C}_{13: 0}, \mathrm{C}_{15: 0}$, $\mathrm{C}_{17: 0}$, and $\mathrm{C}_{19: 0}$ ), representative of heterotrophic bacterial biomass (Perry et al. 1979), and polyunsaturated fatty acids (PUFA; summed excess ${ }^{13} \mathrm{C}$ in $\mathrm{C}_{20: 4}, \mathrm{C}_{20: 5}$, $\mathrm{C}_{22: 5}$, and $\mathrm{C}_{22: 6}$ ), representative of algal biomass (Volkman et al. 1998).

Field monitoring. Concurrent with the mesocosm experiment, we conducted field measurements of various water column and sediment parameters at the sediment collection sites within each lagoon on 2 sampling dates. Triplicate measurements of water temperature and salinity were taken using a YSI datasonde during each sampling. Triplicate samples for sediment per- cent OM and benthic chl a concentrations were also collected and measured as described above for the mesocosm experiment. We also monitored macroalgal biomass from May through October 2006. Macroalgae samples $(\mathrm{n}=3)$ were collected at multiple sites across HIB $(n=9)$ and IWB $(n=5)$ by randomly tossing a cylinder (0.42 $\mathrm{m}$ i.d.) and collecting the total biomass contained within the cylinder. The algae were dried at $40^{\circ} \mathrm{C}$ and normalized to the cylinder area for biomass $\left(\mathrm{g} \mathrm{DW} \mathrm{m} \mathrm{m}^{-2}\right.$ ). The triplicate biomass values for each site were averaged to obtain a site biomass estimate. Since this experiment was designed to simulate a die-off event following a bloom, we report the ranges over the growing season of maximum biomass estimates for each site as well as the mean \pm SE for all sites within each lagoon (Table 1).

Data analysis. We applied repeated measures ANOVA to examine the effects of lagoon (HIB vs. IWB) and time (Days 0, 1, 2, 7, 14) on the sediment parameters using the Mixed procedure in SAS 9.1 (SAS Institute). In all models, a first-order ante-dependence error structure (Kenward 1987) was used to model the within-subject covariance structure. We present results from the Type III test of fixed effects from the ANOVA model. To further explain the effects of time, post hoc contrasts were used to compare the isotopic enrichment parameters for Days 1 and 2 with Days 7 and 14. Unless otherwise noted, mesocosm values presented are means \pm 1 SE for 3 replicates.

\section{RESULTS}

\section{Field and experimental conditions}

Temperatures and salinities in the mesocosms were similar to values measured at the field sites during June (Table 1). Though temperatures in the mesocosms were lower than in the field by $\sim 6^{\circ} \mathrm{C}$, the values were well within the ranges of water temperatures typically observed throughout a day and between days in these shallow lagoons (Giordano 2009). Betweenlagoon differences in organic content and benthic chl a concentrations in mesocosm sediments were also similar to those observed at the field sites (Table 1). The surface $(0-1 \mathrm{~cm})$ sediment organic content within HIB mesocosms was approximately twice as high as in IWB. These values represent means $\pm \mathrm{SE}(\mathrm{n}=15)$ over 5 sampling days, since sediment OM did not accumulate in either treatment over the course of the experiment (Table 2). In addition, benthic chl a concentrations were lower at HIB in the surface sediments than at IWB (Table 1). Again, these values represent means $\pm \mathrm{SE}$ ( $\mathrm{n}=15)$, since benthic chl a did not accumulate in either treatment over the experiment (Table 2). Simi- 
Table 2. Mean $( \pm \mathrm{SE})$ values for bulk sediment parameters $(n=3)$ in Hog Island Bay $(\mathrm{HIB})$ and Isle of Wight Bay (IWB). Last 3 columns show p-values for repeated-measures ANOVA used to test for differences in lagoons over time for various sediment pools. Significant p-values are indicated in bold. THAAs: total hydrolyzable amino acids (AAs); PLFAs: phospholipid-linked fatty acids; OC: organic content

\begin{tabular}{|c|c|c|c|c|c|c|c|c|c|}
\hline \multirow{2}{*}{ Parameter } & \multirow{2}{*}{ Lagoon } & \multicolumn{5}{|c|}{ - Experimental day } & \multirow[b]{2}{*}{ Lagoon } & \multicolumn{2}{|c|}{ ANOVA } \\
\hline & & 0 & 1 & 2 & 7 & 14 & & Time & Interaction \\
\hline \multirow{2}{*}{$\begin{array}{l}\text { Organic matter } \\
(\%)\end{array}$} & HIB & $1.82(0.48)$ & $2.52(0.70)$ & $1.84(0.11)$ & $1.75(0.31)$ & $2.12(0.22)$ & \multirow[t]{2}{*}{0.0008} & \multirow[t]{2}{*}{0.6708} & \multirow[t]{2}{*}{0.6958} \\
\hline & IWB & $1.20(0.26)$ & $0.93(0.21)$ & $0.96(0.04)$ & $0.89(0.12)$ & $1.22(0.14)$ & & & \\
\hline \multirow{2}{*}{$\begin{array}{l}\text { Chlorophyll } a \\
\left(\mathrm{mg} \mathrm{chl} \mathrm{a} \mathrm{m}^{-2}\right)\end{array}$} & HIB & $15.0(2.5)$ & $29.0(3.4)$ & $28.1(8.6)$ & $29.0(6.8)$ & 33.7 (8.6) & \multirow[t]{2}{*}{0.0010} & \multirow[t]{2}{*}{0.3187} & \multirow[t]{2}{*}{0.9870} \\
\hline & IWB & $93.7(7.7)$ & $108(24)$ & $112(21)$ & $110(4)$ & $124(16)$ & & & \\
\hline \multirow{2}{*}{$\begin{array}{l}\text { THAAs } \\
\left(\mu \mathrm{mol} \text { AA } \mathrm{mg} \mathrm{OC}^{-1}\right)\end{array}$} & HIB & 3.44 & $3.95(0.70)$ & $2.29(0.04)$ & $1.91(0.17)$ & $2.24(0.11)$ & \multirow[t]{2}{*}{0.7074} & \multirow[t]{2}{*}{0.0023} & \multirow[t]{2}{*}{0.3591} \\
\hline & IWB & 3.74 & $3.28(0.28)$ & $2.90(0.15)$ & $2.16(0.13)$ & $2.35(0.27)$ & & & \\
\hline \multirow{2}{*}{$\begin{array}{l}\text { PLFAs } \\
\left(\mu g \text { PLFA mg } \mathrm{OC}^{-1}\right)\end{array}$} & HIB & $14.5(5.4)$ & $13.9(3.6)$ & $9.13(1.78)$ & $19.7(1.5)$ & 14.9 (1.9) & \multirow[t]{2}{*}{0.7033} & \multirow[t]{2}{*}{0.1893} & \multirow[t]{2}{*}{0.4235} \\
\hline & IWB & $15.7(2.3)$ & $11.9(0.7)$ & $14.2(3)$ & $13.9(1.2)$ & $19.5(5.0)$ & & & \\
\hline
\end{tabular}

larly, organic content at the field sites was higher in HIB, while benthic chl a concentrations were higher in IWB (Table 1). Peak macroalgal biomass from May through October 2006 ranged across the field sites from 0 to 192 and 29 to $538 \mathrm{~g} \mathrm{DW} \mathrm{m}^{-2}$ for HIB (n = 9) and IWB $(n=5)$, respectively (Table 1$)$. The biomass of dead macroalgae added to the mesocosms fell within these ranges; approximately twice as much algae was added to the IWB treatments to reflect the higher macroalgal densities there.

\section{Bulk isotopes}

All sediment pools displayed similar isotopic enrichment patterns. Excess ${ }^{13} \mathrm{C}$ and ${ }^{15} \mathrm{~N}$ in bulk sediments $(0-1 \mathrm{~cm})$ are presented in Fig. $2 .{ }^{13} \mathrm{C}$ appeared in mesocosms from both lagoons immediately following the addition of macroalgae (Day 1, $22.03 \pm 0.29$ and 62.76 $\pm 21.91 \mathrm{nmol}^{13} \mathrm{C} \mathrm{g} \mathrm{DW}^{-1}$ for HIB and IWB, respectively) and excess ${ }^{13} \mathrm{C}$ values were similar on Day 2. Individual replicates (data not shown) peaked on either Day 7 or 14, which accounted for the large variance associated with the means for those days. Nevertheless, post hoc contrasts indicated that excess ${ }^{13} \mathrm{C}$ values were significantly higher on Days 7 and 14 than on Days 1 and 2 (Table 3, Fig. 2a). Excess ${ }^{15} \mathrm{~N}$ followed the same pattern as ${ }^{13} \mathrm{C}$ : label first appeared on Day 1 $\left(28.94 \pm 5.96\right.$ and $79.61 \pm 36.27 \mathrm{nmol}^{15} \mathrm{~N} \mathrm{~g} \mathrm{DW}^{-1}$ for HIB and IWB, respectively), and values peaked on either Day 7 or 14. Again, post hoc contrasts showed higher excess ${ }^{15} \mathrm{~N}$ on Days 7 and 14 than Days 1 and 2 (Table 3, Fig. 2b). There were no significant lagoon differences in either excess ${ }^{13} \mathrm{C}$ or ${ }^{15} \mathrm{~N}$ for bulk sediments (Table 3), and both lagoons showed similar patterns of initial uptake on Day 1 and maximum values on Day 7 or 14. Maximum isotopic enrichments were well above natural abundance levels $\left(\sim 200 \%\right.$ o $\delta^{13} \mathrm{C}$ and $>4000 \%$ $\delta^{15} \mathrm{~N}$ relative to $-14 \% \delta^{13} \mathrm{C}$ and $\left.\sim 10 \% \delta^{15} \mathrm{~N}\right)$. Given the maximum isotopic enrichments for each mesocosm and the masses of ${ }^{13} \mathrm{C}$ and ${ }^{15} \mathrm{~N}$ that were added to each mesocosm as macroalgal material, we estimated that $6.4 \pm 1.4$ and $35.1 \pm 10.3 \%$ of the added macroalgal ${ }^{13} \mathrm{C}$ and ${ }^{15} \mathrm{~N}$ were incorporated into the sediments $(0-1 \mathrm{~cm})$ for HIB. In IWB, $2.9 \pm 0.9$ and $8.8 \pm 2.1 \%$ of the macroalgal ${ }^{13} \mathrm{C}$ and ${ }^{15} \mathrm{~N}$ were incorporated into the sediments.

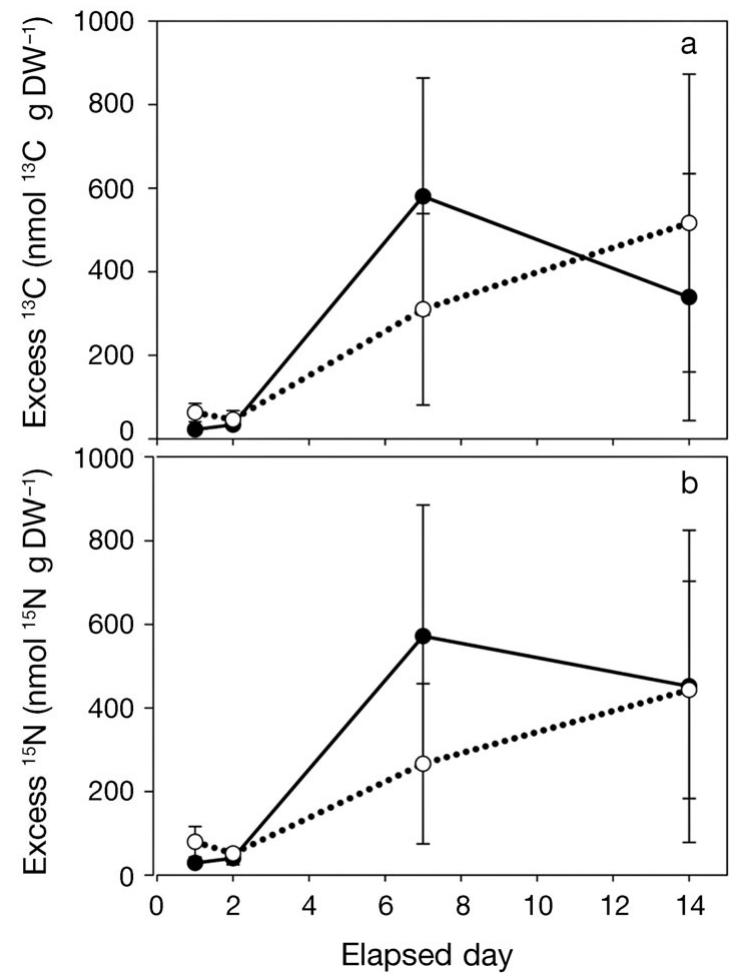

Fig. 2. Bulk sediment isotopic enrichments for Hog Island Bay $(\bullet$, solid lines) and Isle of Wight Bay $(0$, dotted lines). Values are reported as means $\pm 1 \mathrm{SE}(\mathrm{n}=3)$ for excess $(\mathrm{a}){ }^{13} \mathrm{C}$ and $(\mathrm{b}){ }^{15} \mathrm{~N}$ 
Table 3. Results of 2-factor repeated measures ANOVA used to test for differences in lagoons over time for isotopic enrichments $\left({ }^{13} \mathrm{C}\right.$ or $\left.{ }^{15} \mathrm{~N}\right)$ of various sediment pools and percent enrichment of select sediment pools out of the bulk sediment enrichment. Results for the post hoc contrast for Days 1 and 2 versus Days 7 and 14 are shown to the right. One outlier was removed from the Isle of Wight Bay (IWB) ${ }^{15} \mathrm{~N}$ total hydrolyzable amino acid (THAA) analyses (Day 2) and the Hog Island Bay ${ }^{13} \mathrm{C}$ phospholipidlinked fatty acid (PLFA) analyses (Day 1) due to methodological errors, which accounts for the reduced degrees of freedom for those parameters. Significant p-values are indicated in bold

\begin{tabular}{|c|c|c|c|c|c|c|c|c|c|c|c|c|c|}
\hline \multirow[t]{2}{*}{ Parameter } & \multirow[t]{2}{*}{ Isotope } & \multicolumn{3}{|c|}{ Lagoon } & \multicolumn{3}{|c|}{ Time } & \multicolumn{3}{|c|}{ Interaction } & \multicolumn{3}{|c|}{ Post hoc contrast } \\
\hline & & df & $F$ & $\mathrm{p}$ & df & $F$ & $\mathrm{p}$ & $\mathrm{df}$ & $F$ & $\mathrm{p}$ & $\mathrm{df}$ & $F$ & $\mathrm{p}$ \\
\hline \multirow[t]{2}{*}{ Bulk sediments } & ${ }^{13} \mathrm{C}$ & 4 & 0.01 & 0.9163 & 12 & 6.98 & 0.0057 & 12 & 3.29 & 0.0580 & 12 & 19.16 & 0.0009 \\
\hline & ${ }^{15} \mathrm{~N}$ & 4 & 0.42 & 0.5532 & 12 & 5.76 & 0.0112 & 12 & 0.8 & 0.5168 & 12 & 15.61 & 0.0019 \\
\hline \multirow{2}{*}{ THAA } & ${ }^{13} \mathrm{C}$ & 4 & 0.25 & 0.6460 & 12 & 3.68 & 0.0434 & 12 & 1.57 & 0.2487 & 12 & 10.37 & 0.0074 \\
\hline & ${ }^{15} \mathrm{~N}$ & 4 & 0.92 & 0.3921 & 11 & 3.63 & 0.0485 & 11 & 1.56 & 0.2542 & 11 & 9.93 & 0.0092 \\
\hline \multirow[t]{2}{*}{ D-Ala } & ${ }^{13} \mathrm{C}$ & 4 & 1.14 & 0.3461 & 12 & 2.21 & 0.1399 & 12 & 1.03 & 0.4147 & 12 & 5.16 & 0.0424 \\
\hline & ${ }^{15} \mathrm{~N}$ & 4 & 2.76 & 0.1721 & 11 & 1.98 & 0.1755 & 11 & 1.05 & 0.4086 & 11 & 4.89 & 0.0492 \\
\hline \multirow[t]{2}{*}{ D/L-Ala } & ${ }^{13} \mathrm{C}$ & 4 & 5.92 & 0.0718 & 12 & 5.49 & 0.0132 & 12 & 1.21 & 0.3473 & 12 & 15.7 & 0.0019 \\
\hline & ${ }^{15} \mathrm{~N}$ & 4 & 7.72 & 0.0499 & 11 & 17.83 & 0.0002 & 11 & 5.25 & 0.0171 & 11 & 16.21 & 0.0020 \\
\hline PLFA & ${ }^{13} \mathrm{C}$ & 4 & 0.79 & 0.4247 & 11 & 3.32 & 0.0605 & 11 & 1.06 & 0.4037 & 11 & 6.93 & 0.0233 \\
\hline Bacterial FA & ${ }^{13} \mathrm{C}$ & 4 & 1.11 & 0.3507 & 11 & 3.39 & 0.0575 & 11 & 1.08 & 0.3961 & 11 & 5.83 & 0.0344 \\
\hline Algal FA & ${ }^{13} \mathrm{C}$ & 4 & 0.68 & 0.4566 & 11 & 6.84 & 0.0072 & 11 & 1.61 & 0.2426 & 11 & 17.11 & 0.0017 \\
\hline \multirow[t]{2}{*}{ THAA/Bulk (\%) } & ${ }^{13} \mathrm{C}$ & 4 & 6.38 & 0.0649 & 12 & 2.86 & 0.0815 & 12 & 0.57 & 0.6474 & 12 & 5.62 & 0.0353 \\
\hline & ${ }^{15} \mathrm{~N}$ & 4 & 1.35 & 0.3102 & 11 & 7.8 & 0.0046 & 11 & 0.3 & 0.8255 & 11 & 19.83 & 0.0010 \\
\hline \multirow[t]{2}{*}{ D-Ala/Bulk (\%) } & ${ }^{13} \mathrm{C}$ & 4 & 13.48 & 0.0214 & 12 & 13.08 & 0.0004 & 12 & 3.03 & 0.0712 & 12 & 33.01 & $<0.0001$ \\
\hline & ${ }^{15} \mathrm{~N}$ & 4 & 6.29 & 0.0662 & 11 & 16.59 & 0.0002 & 11 & 3.64 & 0.0483 & 11 & 15.59 & 0.0023 \\
\hline PLFA/Bulk (\%) & ${ }^{13} \mathrm{C}$ & 4 & 0.58 & 0.4905 & 11 & 1.65 & 0.2338 & 11 & 1.55 & 0.2569 & 11 & 0.96 & 0.3476 \\
\hline
\end{tabular}

\section{Hydrolyzable amino acids}

All biomarker concentrations were normalized to sediment TOC to account for the differences in organic content between HIB and IWB. THAA concentrations were 3.22 and $3.74 \mu \mathrm{mol} \mathrm{AA} \mathrm{mg} \mathrm{OC}^{-1}$ on Day 0 for HIB and IWB, respectively, and decreased slightly over the course of the experiment; there were no significant lagoon differences (Table 2). THAA represented a stable fraction of the sediment organic content, comprising $\sim 13 \%$ of the TOC and $\sim 30 \%$ of the TN. Excess ${ }^{13} \mathrm{C}$ and ${ }^{15} \mathrm{~N}$ in the THAA pool (summed excess ${ }^{13} \mathrm{C}$ and ${ }^{15} \mathrm{~N}$ in the individual amino acids) were lower than in the bulk pool, but displayed similar patterns, showing enrichments well above natural abundance; for THAA, maximum values of $\delta^{13} \mathrm{C}$ and $\delta^{15} \mathrm{~N}$ were $>500 \%$ and $>6000 \%$, whereas background values were approximately $-15 \%$ and $20 \%$ for $\delta^{13} \mathrm{C}$ and $\delta^{15} \mathrm{~N}$, respectively. Excess ${ }^{13} \mathrm{C}$ appeared in both lagoons immediately following the macroalgal addition (Day 1, $10.34 \pm 1.43$ and $26.10 \pm 13.46 \mathrm{nmol}^{13} \mathrm{C} \mathrm{g} \mathrm{DW}^{-1}$ for HIB and IWB, respectively) and peaked on either Day 7 or 14 (Fig. 3a). Excess ${ }^{15} \mathrm{~N}$ followed the same pattern as ${ }^{13} \mathrm{C}$ : label first appeared on Day $1(13.80 \pm 2.87$ and $35.73 \pm$ $12.02 \mathrm{nmol}^{15} \mathrm{~N} \mathrm{~g} \mathrm{DW}^{-1}$ for HIB and IWB, respectively), and values peaked on either Day 7 or 14 (Fig. 3b). There were no significant lagoon differences for excess ${ }^{13} \mathrm{C}$ or ${ }^{15} \mathrm{~N}$ in THAA; however, there were significant time effects. Post hoc contrasts indicated that excess ${ }^{13} \mathrm{C}$ and ${ }^{15} \mathrm{~N}$ on Days 7 and 14 were significantly higher than on Days 1 and 2 (Table 3, Fig. 3a,b). Across all sampling days, excess ${ }^{13} \mathrm{C}$ and ${ }^{15} \mathrm{~N}$ in THAA accounted for an average of $\sim 40 \%$ (range $=11$ to $75 \%$ ) of excess ${ }^{13} \mathrm{C}$ and ${ }^{15} \mathrm{~N}$ in bulk sediments, although the ${ }^{13} \mathrm{C}$ and ${ }^{15} \mathrm{~N}$ accounted for a greater fraction of the ${ }^{13} \mathrm{C}$ and ${ }^{15} \mathrm{~N}$ in bulk sediment on Days 1 and 2 than on Days 7 and 14 (Tables 3 \& 4).

Excess ${ }^{13} \mathrm{C}$ and ${ }^{15} \mathrm{~N}$ in individual amino acids provided additional information about the fate of macroalgal $\mathrm{C}$ and $\mathrm{N}$ within the sediment microbial pool. Excess ${ }^{13} \mathrm{C}$ (corrected for hydrolysis-induced racemization) appeared in D-Ala, a bacterial-specific amino acid, on Day 1 in sediments from both bays (HIB: $0.05 \pm$ $0.01 \mathrm{nmol}{ }^{13} \mathrm{C} \mathrm{g} \mathrm{DW}^{-1}$; IWB: $0.05 \pm 0.02 \mathrm{nmol}{ }^{13} \mathrm{C} \mathrm{g}$ $\mathrm{DW}^{-1}$ ) and peaked on Day 7 or 14 (Fig. 3c, Table 3). Similarly, ${ }^{15} \mathrm{~N}$ appeared on Day 1 (HIB: $0.06 \pm$ $0.03 \mathrm{nmol}{ }^{13} \mathrm{C} \mathrm{g} \mathrm{DW}^{-1}$; IWB: $0.08 \pm 0.04 \mathrm{nmol}^{15} \mathrm{~N} \mathrm{~g}$ $\mathrm{DW}^{-1}$ ) and peaked on Day 7 or 14 (Fig. 3d, Table 3). While the absolute values for excess ${ }^{13} \mathrm{C}$ and ${ }^{15} \mathrm{~N}$ were low on Days 1 and 2 and increased throughout the experiment, the proportion of excess ${ }^{13} \mathrm{C}$ and ${ }^{15} \mathrm{~N}$ in the bulk sediment pool that appeared in D-Ala was highest on Days 1 and 2 and then decreased through Day 14 (Tables $3 \& 4$ ).

Additionally, the D/L-Ala ratio of excess isotope (either ${ }^{13} \mathrm{C}$ or ${ }^{15} \mathrm{~N}$, not corrected for hydrolysis-induced racemization) indicated the relative importance of bacterial uptake to total label uptake (Veuger et al. 2005; 

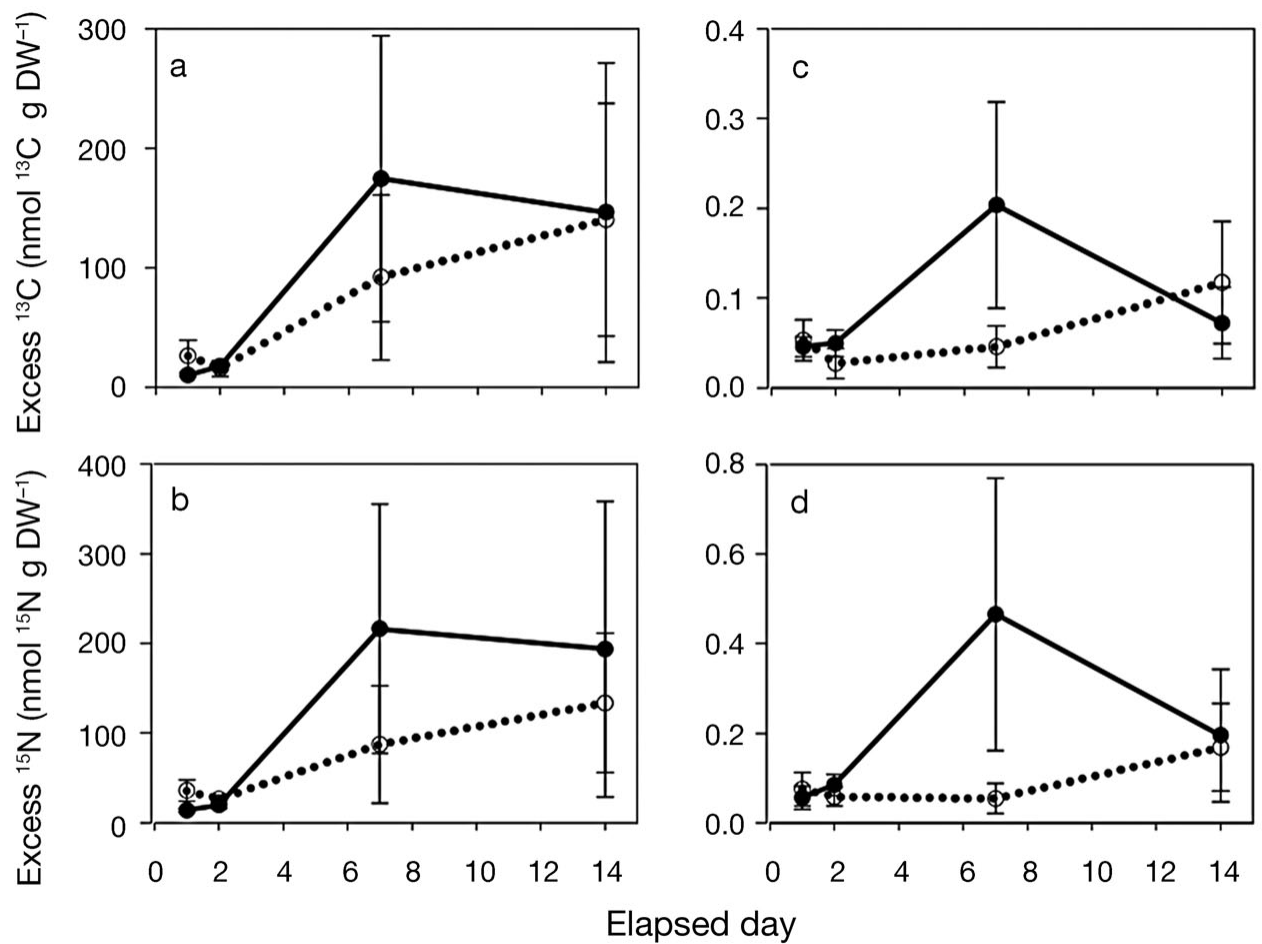

Fig. 3. Amino acid isotopic enrichments for Hog Island Bay (solid lines) and Isle of Wight Bay (dotted lines). Values are means \pm $1 \mathrm{SE}\left(\mathrm{n}=3\right.$ ) for excess (a) ${ }^{13} \mathrm{C}$ and $(\mathrm{b}){ }^{15} \mathrm{~N}$ in total hydrolyzable amino acids and excess (c) ${ }^{13} \mathrm{C}$ and $(\mathrm{d}){ }^{15} \mathrm{~N}$ in $\mathrm{D}$-Ala

Fig. 4). The values for excess ${ }^{13} \mathrm{C}$ and ${ }^{15} \mathrm{~N}$ in $\mathrm{D} / \mathrm{L}-\mathrm{Ala}$ showed similar patterns (Fig. $4 \mathrm{a}, \mathrm{b})$. Excess ${ }^{13} \mathrm{C}$ in $\mathrm{D} / \mathrm{L}-$ Ala peaked for both bays on Day 1 (HIB: $0.053 \pm 0.006$; IWB: $0.042 \pm 0.007)$ and decreased by Day 14 (HIB: $0.031 \pm 0.005$; IWB: $0.029 \pm 0.002$; Fig. $4 \mathrm{a}$ ). This represented a decrease from Day 1 to Day 14 from 100 to

Table 4. Fraction (\%) of excess isotope $\left({ }^{13} \mathrm{C}\right.$ or $\left.{ }^{15} \mathrm{~N}\right)$ in total hydrolysable amino acids (THAAs), D-Ala, and phospholipid-linked fatty acids (PLFAs) out of excess isotope in bulk sediment. Values are presented as the mean $( \pm \mathrm{SE}, \mathrm{n}=3)$ for each lagoon on each experimental day. HIB: Hog Island Bay; IWB: Isle of Wight Bay

\begin{tabular}{|c|c|c|c|c|c|}
\hline \multirow{2}{*}{$\begin{array}{l}\text { Parameter } \\
\text { Lagoon }\end{array}$} & \multirow{2}{*}{ Isotope } & \multicolumn{4}{|c|}{ Experimental day } \\
\hline & & 1 & 2 & 7 & 14 \\
\hline \multicolumn{6}{|c|}{ THAAs/Bulk (\%) } \\
\hline \multirow[t]{2}{*}{ HIB } & ${ }^{13} \mathrm{C}$ & $47.1(7.1)$ & $51.0(4.5)$ & $26.4(7.6)$ & $50.9(12.5)$ \\
\hline & ${ }^{15} \mathrm{~N}$ & $47.7(1.5)$ & $56.1(9.1)$ & $33.8(5.1)$ & $39.1(2.7)$ \\
\hline \multirow[t]{2}{*}{ IWB } & ${ }^{13} \mathrm{C}$ & $37.1(6.5)$ & $38.9(10.3)$ & $30.3(5.4)$ & $31.3(5.5)$ \\
\hline & ${ }^{15} \mathrm{~N}$ & $49.3(8.3)$ & 42.1 (10.9) & $30.7(2.5)$ & $33.2(4.7)$ \\
\hline \multicolumn{6}{|c|}{ D-Ala/Bulk (\%) } \\
\hline \multirow[t]{2}{*}{ HIB } & ${ }^{13} \mathrm{C}$ & $0.21(0.05)$ & $0.14(0.03)$ & $0.04(0.01)$ & $0.06(0.03)$ \\
\hline & ${ }^{15} \mathrm{~N}$ & $0.19(0.07)$ & $0.23(0.03)$ & $0.07(0.01)$ & $0.05(0.01)$ \\
\hline \multirow[t]{2}{*}{ IWB } & ${ }^{13} \mathrm{C}$ & $0.08(0.01)$ & $0.06(0.03)$ & $0.02(0.01)$ & $0.04(0.01)$ \\
\hline & ${ }^{15} \mathrm{~N}$ & $0.10(0.02)$ & $0.10(0.04)$ & $0.03(0.01)$ & $0.04(0.01)$ \\
\hline \multicolumn{6}{|c|}{ PLFA/Bulk (\%) } \\
\hline HIB & ${ }^{13} \mathrm{C}$ & $3.46(0.17)$ & $2.94(0.57)$ & $3.53(0.97)$ & 4.89 (3.79) \\
\hline IWB & ${ }^{13} \mathrm{C}$ & $2.85(1.01)$ & $3.43(1.09)$ & $3.05(0.59)$ & $0.22(0.01)$ \\
\hline
\end{tabular}

$41 \%$ bacterial ${ }^{13} \mathrm{C}$ incorporation for HIB and 77 to $36 \%$ for IWB (Fig. 4a, right axis). Excess ${ }^{15} \mathrm{~N}$ in $\mathrm{D} / \mathrm{L}-\mathrm{Ala}$ peaked on Day 2 for HIB and Day 1 for IWB (HIB: $0.048 \pm 0.003$; IWB: $0.033 \pm 0.005)$ and decreased by Day 14 (HIB: $0.028 \pm 0.003$; IWB: $0.027 \pm 0.0004$ ). This represented a decrease over the $14 \mathrm{~d}$ from 100 to $33 \%$ bacterial ${ }^{15} \mathrm{~N}$ incorporation for HIB and 49 to $32 \%$ for IWB (Fig. 4 b, right axis). Even though excess ${ }^{13} \mathrm{C}$ D/L-Ala in HIB showed a trend of being higher than IWB, the treatments were not significantly different; however, excess ${ }^{15} \mathrm{~N}$ in D/L-Ala was significantly higher for sediments from HIB than IWB (Table 3, Fig. 4).

\section{Phospholipid-linked fatty acids}

Total PLFA concentrations, normalized to sediment TOC, remained steady throughout the experiment, and sediments from both lagoons had similar concentrations ( 15 $\mu \mathrm{g}$ PLFA mg OC ${ }^{-1}$; Table 2). PLFA represented $\sim 1 \%$ of the sediment TOC for HIB and IWB. Excess ${ }^{13} \mathrm{C}$ in total PLFAs were 


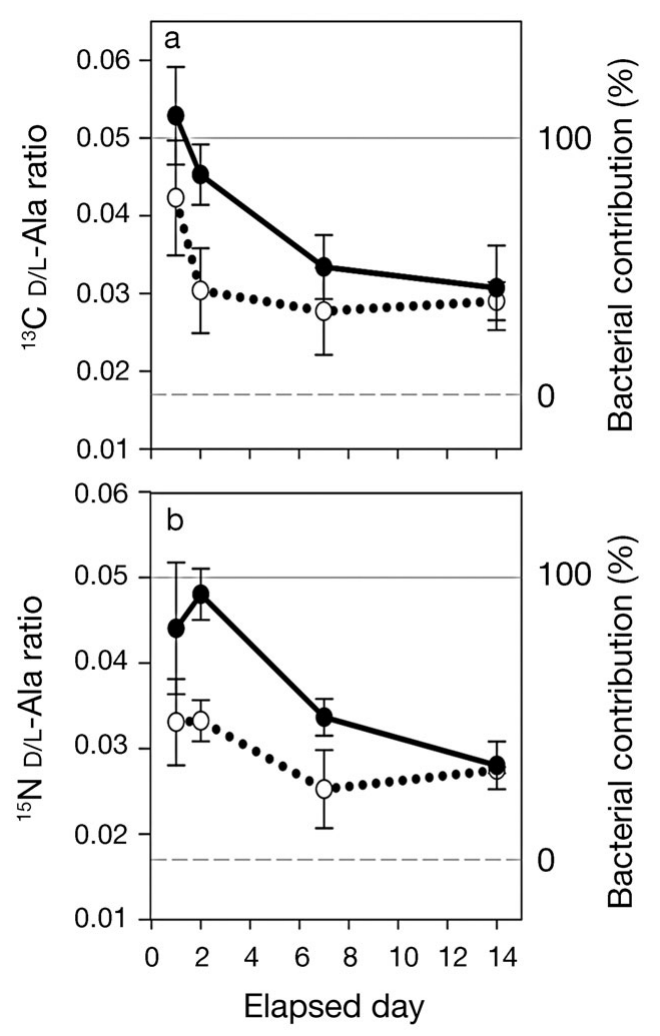

Fig. 4. Ratio of excess ${ }^{13} \mathrm{C}$ (a) or ${ }^{15} \mathrm{~N}$ (b) in D/L-Ala for Hog Island Bay $(\bullet$, solid lines) and Isle of Wight Bay ( $\mathrm{O}$, dotted lines). Values are means $\pm 1 \mathrm{SE}(\mathrm{n}=3)$. Horizontal dashed gray lines represent the racemization background (0.017). Horizontal solid gray lines represent bacterial D/L-Ala abundance ratio (0.05). Values on the right $y$-axes correspond to estimates of bacterial contribution to total label incorporation

lower than in bulk and THAA pools, but followed a similar pattern. Label first appeared on Day 1 (HIB: $0.77 \pm 0.03 \mathrm{nmol}^{13} \mathrm{C} \mathrm{g} \mathrm{DW}^{-1}$; IWB: $2.14 \pm 1.34 \mathrm{nmol}^{13} \mathrm{C}$ g $\mathrm{DW}^{-1}$ ) and peaked on Day 7 or 14 (Fig. 5a). There were no lagoon effects, but excess ${ }^{13} \mathrm{C}$ values were significantly lower on Days 1 and 2 than on Days 7 and 14 (Table 3, Fig. 5a). Averaged over the entire experiment, excess ${ }^{13} \mathrm{C}$ in PLFAs accounted for $\sim 3 \%$ (range: 1.4 to $3.5 \%$ ) of excess ${ }^{13} \mathrm{C}$ in bulk sediments for both lagoons (Tables $3 \& 4$ ). Linear regressions of excess ${ }^{13} \mathrm{C}$ in PLFAs vs. excess ${ }^{13} \mathrm{C}$ in THAAs showed good agreement (HIB: $\mathrm{r}^{2}=0.72, \mathrm{p}=0.001$; IWB: $\mathrm{r}^{2}=0.96, \mathrm{p}<$ 0.001), suggesting that microbial biomarkers in each compound class tracked one another.

Excess ${ }^{13} \mathrm{C}$ in groups of individual PLFAs provided additional information about the importance of specific sediment microbial pools in the cycling of macroalgal $\mathrm{C}$ and N. Excess ${ }^{13} \mathrm{C}$ appeared in BrFAs, representative of heterotrophic bacterial biomass (Perry et al. 1979), on Day 1 for both bays (HIB: $0.03 \pm 0.02 \mathrm{nmol}{ }^{13} \mathrm{C} \mathrm{g}$ $\mathrm{DW}^{-1}$; IWB: $0.12 \pm 0.04 \mathrm{nmol}^{13} \mathrm{C} \mathrm{g} \mathrm{DW}^{-1}$ ) and peaked

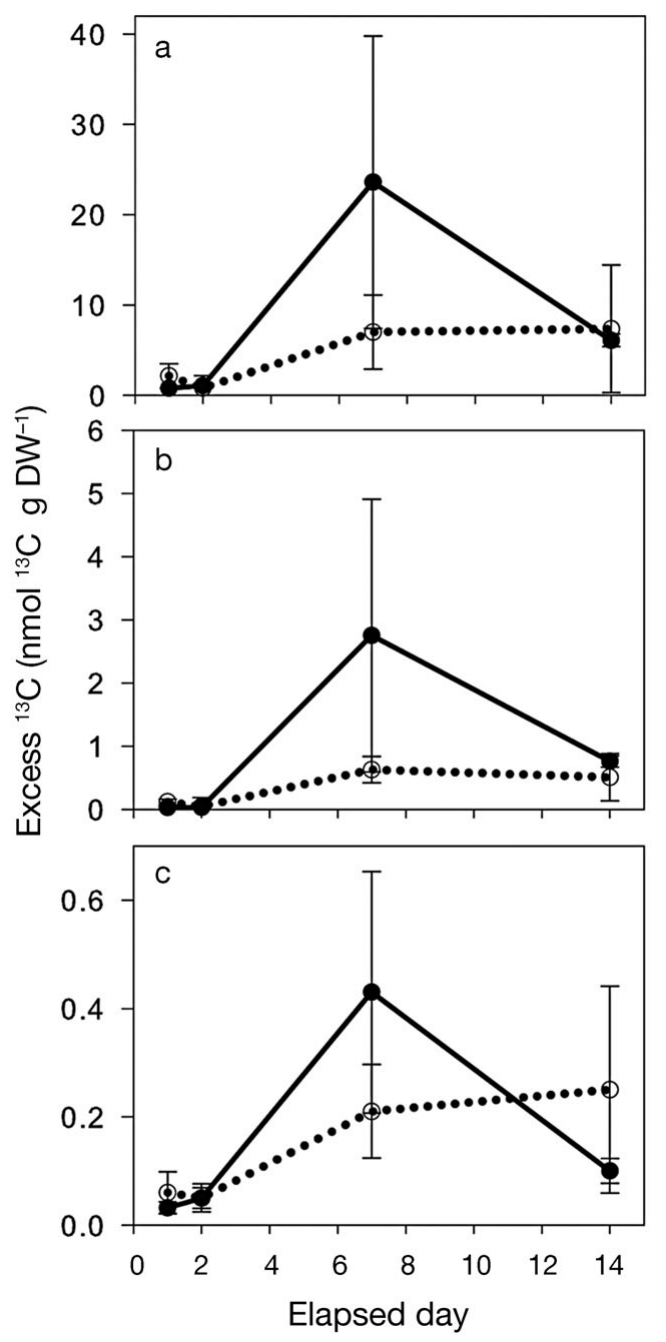

Fig. 5. Phospholipid-linked fatty acid (PLFA) isotopic enrichments for Hog Island Bay $(\bullet$, solid lines) and Isle of Wight Bay $\left(\mathrm{O}\right.$, dotted lines). Values are means $\pm 1 \mathrm{SE}(\mathrm{n}=3)$ for excess ${ }^{13} \mathrm{C}$ in (a) total PLFA, (b) branched odd fatty acids, which represent heterotrophic bacteria, and (c) polyunsaturated fatty acids, which represent algae

on Day 7 or 14 (Fig. 5b; Table 3). Values of excess ${ }^{13} \mathrm{C}$ in BrFAs were linearly related to excess ${ }^{13} \mathrm{C}$ in D-Ala, another bacterial-specific biomarker (HIB: $\mathrm{r}^{2}=0.95, \mathrm{p}<$ 0.0001; IWB: $\left.\mathrm{r}^{2}=0.93, \mathrm{p}<0.0001\right)$. Excess ${ }^{13} \mathrm{C}$ also appeared in PUFAs, representative of algal biomass (Volkman et al. 1998), on Day 1 (HIB: $0.03 \pm 0.01 \mathrm{nmol}$ ${ }^{13} \mathrm{C} \mathrm{g} \mathrm{DW}^{-1}$; IWB: $0.06 \pm 0.04 \mathrm{nmol}^{13} \mathrm{C} \mathrm{g} \mathrm{DW}^{-1}$ ) and peaked on Day 7 or 14 (Fig. $5 \mathrm{c}$, Table 3). Overall, ${ }^{13} \mathrm{C}$ enrichments in PUFAs were lower than for BrFAs. Linear regressions of excess ${ }^{13} \mathrm{C}$ in BrFAs and PUFAs suggested that this trend was consistent across all time points and the fatty acid groups showed good agreement (HIB: $\mathrm{r}^{2}=0.92, \mathrm{p}<0.0001$; IWB: $\mathrm{r}^{2}=0.86, \mathrm{p}<$ 0.0001). 


\section{DISCUSSION}

We conducted this experiment to simulate the die-off of a macroalgal bloom, an annual event common to many coastal lagoons worldwide (Sfriso et al. 1992, Valiela et al. 1997). We selected field sites for collecting sediment and macroalgae within 2 lagoons representative of coastal bays along the US East Coast. Both sites have sandy sediments, are similar in water depth ( 1 $\mathrm{m}$ deep at mean low water), and are exposed to similar light levels. Although the organic content of the sediments differed significantly between the bays, the values still fell within a relatively narrow range of 0.6 to $3.8 \%$, typical of many coastal bays. Differences in benthic chl a concentrations in the mesocosms, which were consistent with differences in the field, were more pronounced than organic content and likely influenced the processing of macroalgal ${ }^{13} \mathrm{C}$ and ${ }^{15} \mathrm{~N}$ in the sediments.

Since this experiment investigated the fate of dead macroalgae, we freeze-dried the macroalgae prior to adding it to the mesocosms. Although previous macroalgal decomposition studies have used frozen macroalgae (Buchsbaum et al. 1991, Nedergaard et al. 2002, Castaldelli et al. 2003, García-Robledo et al. 2008), we were unable to use frozen macroalgae for logistical reasons (i.e. lack of a freezer at our remote field station). Other studies have used buried live macroalgae (Franke et al. 2006, Rossi 2007); we did not feel that burial of the algae in the sediments adequately represented the natural die-off process, which occurs at the sediment-water interface. Numerous phytoplankton fate studies have used freeze-dried material (Moodley et al. 2000, Aberle \& Witte 2003, Witte et al. 2003). After $1 \mathrm{wk}$, macroalgae were no longer visible in our mesocosms, indicating that all of the macroalgae was decomposed, remineralized, respired, or fragmented into particle sizes too small to see (either in the water column or sediments), so we are confident that freezedrying was appropriate for the purposes of tracking macroalgal $\mathrm{C}$ and $\mathrm{N}$ into the sediments.

\section{Label incorporation into bulk sediments}

Previous studies have shown that some decomposition of macroalgae occurs in the water column, resulting in release of inorganic and organic nutrients, consumption of dissolved oxygen, and release of toxic sulfides. These processes have been associated with phytoplankton blooms, fish and other faunal kills, as well as seagrass declines (Buchsbaum et al. 1991, Sfriso et al. 1992, Hauxwell et al. 2001, Nedergaard et al. 2002, Cummins et al. 2004). The fate of macroalgal biomass deposited to the sediments, however, is less clear. Our bulk sediment isotope data suggest that a fraction of macroalgal-derived ${ }^{13} \mathrm{C}$ and ${ }^{15} \mathrm{~N}$ appeared in the sediments; however, a smaller percentage of added label appeared in IWB sediments than in HIB sediments, and less ${ }^{13} \mathrm{C}$ appeared than ${ }^{15} \mathrm{~N}$ for both lagoons. In HIB, maximum values of $\sim 6$ and $35 \%$ of macroalgal ${ }^{13} \mathrm{C}$ and ${ }^{15} \mathrm{~N}$ were observed in the sediments. In IWB, $\sim 3$ and $9 \%$ of macroalgal ${ }^{13} \mathrm{C}$ and ${ }^{15} \mathrm{~N}$ were incorporated into the sediments. We were careful not to include visible macroalgal fragments in our samples, so labeling in the sediments should have represented either detrital (macroalgal) particulate or dissolved organic matter (DOM) or transfer of ${ }^{13} \mathrm{C}$ and ${ }^{15} \mathrm{~N}$ to other active pools within the sediments, rather than direct sampling of macroalgal fragments. This is further supported by the uncoupling of ${ }^{13} \mathrm{C}$ and ${ }^{15} \mathrm{~N}$ transferred to the sediments, which suggests that macroalgal $\mathrm{C}$ and $\mathrm{N}$ were transferred disproportionately. We believe that these stoichiometric and lagoonal differences in $\mathrm{C}$ and $\mathrm{N}$ transfer were related to microbial processes, as discussed below.

Sediments showed immediate enrichment in macroalgal ${ }^{13} \mathrm{C}$ and ${ }^{15} \mathrm{~N}$ (Day 1), followed by an increase for 1 to $2 \mathrm{wk}$. While the general trends were similar, replicates were variable suggesting heterogeneity within and/or across mesocosms. Some showed highest enrichments on Day 7; others did not peak until Day 14. This variability likely resulted from patchiness associated with the bloom deposition in our mesocosms or heterogeneity in the sediment microbial communities. Similar patchiness has been observed in field studies (Holmquist 1997, Sfriso \& Marcomini 1999, McGlathery et al. 2001). Despite the observed variability, our statistical analyses confirmed that bulk isotopic enrichments at the end of the experiment (Days $7 \& 14$ ) were higher than at the beginning of the experiment (Days 1 \& 2) for both lagoons, demonstrating accumulation and retention of macroalgal ${ }^{13} \mathrm{C}$ and ${ }^{15} \mathrm{~N}$ in the sediments following the simulated die-off.

Patterns of ${ }^{13} \mathrm{C}$ and ${ }^{15} \mathrm{~N}$ enrichment in THAAs and PLFAs tracked the bulk sediment enrichments. These pools showed immediate isotopic enrichment on Day 1 and peak enrichments on Days 7 or 14. The labeled THAAs and PLFAs in sediments collected on Days 1 and 2 likely represented rapid uptake by microbes, although some microscopic macroalgal detritus may have remained after removal of all visible fragments. The isotopically labeled PLFAs observed in the sediments on Days 7 and 14 most likely represented living microbial biomass given rapid rates of PLFAs turnover (Parkes 1987). THAAs on Days 7 and 14 may have included macroalgal detritus, but we observed no visible fragments of macroalgae by then, suggesting that the biomass had been decomposed. 


\section{Bacterial incorporation of macroalgal label}

Overall, a smaller fraction of macroalgal ${ }^{13} \mathrm{C}$ appeared in the bulk sediments than ${ }^{15} \mathrm{~N}$ for both lagoons. This is consistent with expected preferential uptake of $\mathrm{N}$ by the microbial community since $\mathrm{N}$ is typically the element limiting microbial production and, therefore, is likely to be taken up efficiently, while $\mathrm{C}$ is relatively easily lost by respiration (Kirchman 2000, Howarth \& Marino 2006). More directly, the isotopic enrichments of specific amino acids and fatty acids provided an explicit indication of the communities in the sediments that were taking up macroalgal ${ }^{13} \mathrm{C}$ and ${ }^{15} \mathrm{~N}$. Enrichment of D-Ala and BrFAs clearly demonstrated transfer of macroalgal label to bacterial biomass through decomposition. The correlations between excess ${ }^{13} \mathrm{C}$ in $\mathrm{D}$-Ala and BrFAs provided strong evidence for bacterial ${ }^{13} \mathrm{C}$ uptake, corroborating their use as 2 independent proxies for bacterial biomass. Appearance of the labels on Day 1 showed an immediate response by bacteria to the addition of fresh OM. This rapid response has been shown in previous studies investigating decomposition of macroalgae (Buchsbaum et al. 1991, Nedergaard et al. 2002, Castaldelli et al. 2003, Franke et al. 2006). For example, just minutes after macroalgae were added to sediments, Franke et al. (2006) measured oxygen consumption rates nearly 18 times higher in sediments with macroalgae than in nearby sediments without macroalgae. While others have investigated metabolic responses to the addition of macroalgae, the present study is the first to demonstrate explicitly the incorporation of macroalgal $\mathrm{C}$ and $\mathrm{N}$ into sediment bacterial biomass following a simulated die-off event.

Not only did the bacteria in the present study respond rapidly to the addition of macroalgal biomass, but the bacterial biomarkers also showed prolonged enrichment of ${ }^{13} \mathrm{C}$ and ${ }^{15} \mathrm{~N}$ throughout the $2 \mathrm{wk}$ experiment. The prolonged enrichment of bacterial biomarkers may reflect incorporation into a refractory pool after cell death, which accumulated in the sediments. However, the PLFAs were not likely part of the detrital pool given the rapid turnover of PLFAs after cell death (Parkes 1987, Veuger et al. 2006), and at the time scale of our experiment, we believe accumulation of labeled detrital (bacterial) amino acids was negligible (Veuger et al. 2006). Instead, we believe the continued enrichment of the bacterial biomarkers on Days 7 and 14 is consistent with microbially mediated decomposition of macroalgae. The isotopic labels could persist even longer in the sediments if recycling of macroalgal detritus by bacteria was coupled with BMA metabolism (see 'Bacterial-BMA coupling'). Regardless of the mechanism(s) responsible for the high isotopic enrichments in the bacterial pool, macroalgal ${ }^{13} \mathrm{C}$ and ${ }^{15} \mathrm{~N}$ clearly persisted in the sediments for at least 2 wk following the simulated die-off.

Interestingly, there were no significant betweenlagoon differences in excess isotope levels in bulk sediments, THAAs, or PLFAs, even though twice as much dead macroalgae was added to the IWB mesocosms. We believe that the lower relative enrichments in IWB sediments may be explained by slower decomposition rates. The rates and extent of decomposition are influenced by a variety of environmental, biological, and physical factors (Wakeham \& Canuel 2006). In addition to differences in the amount of macroalgal biomass added to the treatments, the distinguishing characteristic of the lagoon treatments was the sediments and, by default, perhaps the microbial communities within the sediments. It is possible that the IWB sediment bacteria that processed the macroalgal biomass may have been limited in a way that the HIB sediment bacteria were not. For example, some studies have determined hydrolysis to be the rate-limiting step in decomposition (Arnosti 2004 and references therein), either because hydrolysis rates are slow or because the organism required to produce a specific enzyme to break down specific macromolecules is absent or in low abundance. Regardless of the mechanism responsible for limiting retention of macroalgal ${ }^{13} \mathrm{C}$ and ${ }^{15} \mathrm{~N}$ in IWB sediments, this difference could profoundly affect system-wide nutrient cycling. Since macroalgae in both lagoon treatments had visibly disappeared within days following the additions, more macroalgal decomposition likely took place in the IWB water column, which could promote phytoplankton growth and further eutrophication of the system. We measured elevated water column concentrations of $\mathrm{NH}_{4}{ }^{+}$, dissolved inorganic phosphorus (DIP), and dissolved organic $\mathrm{N}$ in mesocosms from both lagoons following addition of macroalgae (data not shown), indicating remineralization of macroalgal detritus in the water column. DIP concentrations were significantly higher in IWB than HIB, possibly reflecting higher rates of remineralization there in response to higher macroalgal biomass. Our results corroborate numerous observations in natural systems demonstrating elevated concentrations of dissolved inorganic and organic nutrients from decomposition of macroalgal material in the water column following a die-off (e.g. Sfriso et al. 1992, Hauxwell et al. 2001, Tyler et al. 2001), but our findings further demonstrate that a fraction of macroalgal detritus is also decomposed and retained within the sediments.

\section{Bacterial-BMA coupling}

The ratio of isotopic enrichments in D/L-Ala provides information on the relative contribution of bacteria and 
algae to total label incorporation. High values of D/LAla indicate a larger contribution from bacteria relative to algae, while the minimum value $(0.017)$ corresponds to zero bacterial or $100 \%$ algal uptake. Excess ${ }^{13} \mathrm{C}$ and ${ }^{15} \mathrm{~N}$ in D/L-Ala was highest for both lagoons on Days 1 and 2 and then decreased throughout the experiment (Fig. 4), suggesting that algae contributed relatively more to total label uptake over time. Because we cannot exclude the possibility that macroalgal detritus may have contributed to the labeled L-Ala pools on Day 14, we estimated maximum contributions from BMA by Day 14 of $~ 60 \%$ of microbial ${ }^{13} \mathrm{C}$ uptake and $\sim 68 \%$ of microbial ${ }^{15} \mathrm{~N}$ uptake (Fig. $4 \mathrm{a}, \mathrm{b}$, right axes). The D/L-Ala ratios for IWB were consistently lower than for HIB until they converged on Day 14, indicating a proportionately lower bacterial contribution to total microbial uptake in IWB. This difference was corroborated by benthic chl a levels in IWB, which were 4 to 5 times the levels found in HIB, indicating a larger BMA population in IWB. The fact that these differences were present on Day 1 suggested that BMA directly took up remineralized nutrients resulting from bacterial decomposition from the water column and/or that label was rapidly transferred from sediment bacteria to BMA. Lastly, ${ }^{13} \mathrm{C}$ enrichment in $\mathrm{C}_{20}$ and $\mathrm{C}_{22}$ PUFAs provided a direct indication of label incorporation by BMA. We observed an initial labeling of the PUFA pool followed by a peak on Day 7 or 14. All of the known BMA-specific fatty acids are also present in many genera of macroalgae, including Gracilaria (Dembitsky et al. 1991, Khotimchenko 2005). Therefore, the $\mathrm{C}_{20}$ PUFA that we used may have represented macroalgal detritus on Days 1 and 2. However, given the low excess ${ }^{13} \mathrm{C}$ in PUFAs on Days 1 and 2 (Fig. 5c) as well as rapid PLFA turnover rates, the PUFAs on Days 7 and 14 most likely represented living BMA rather than macroalgae. Together, these biomarkers supported incorporation of macroalgal ${ }^{13} \mathrm{C}$ and ${ }^{15} \mathrm{~N}$ into BMA biomass.

In Fig. 6, we propose the mechanisms underlying the relationship between BMA, sediment bacteria, and macroalgal detritus in our experimental system. Results from this experiment suggest that macroalgal biomass was decomposed and taken up by heterotrophic bacteria in the surface sediments as DOM. Bacteria incorporated some of the ${ }^{13} \mathrm{C}$ and ${ }^{15} \mathrm{~N}$ into biomass and mineralized the remainder into the sediment pore water as dissolved inorganic (DI) ${ }^{13} \mathrm{C}$ and $\mathrm{DI}^{15} \mathrm{~N}$. Bacteria may have also re-incorporated $\mathrm{DI}^{15} \mathrm{~N}$ if the $\mathrm{N}$ content of the DOM substrate was insufficient to meet the bacterial metabolic demands (Goldman \& Dennett 2000, Veuger et al. 2007a). BMA incorporated $\mathrm{DI}^{13} \mathrm{C}$ and $\mathrm{DI}^{15} \mathrm{~N}$ from the pore water as well as the overlying water column, where macroalgal detritus was also decomposing. BMA have also been shown to take up dissolved organic $\mathrm{N}$ directly (Nilsson \& Sundback 1996). To complete the cycle, bacteria then recycled labeled BMA detritus and/or extrapolymeric substances exuded by the BMA (Smith \& Underwood 1998, Middelburg et al. 2000, Veuger et al. 2007a, Evrard et al. 2008). Good agreement between bacterial and BMA fatty acids supports a tight coupling between these communities $\left(r^{2}=0.93\right.$ and 0.92 for HIB and IWB, respectively), although bacteria have also been shown to recycle nutrients independent of BMA by reincorporating their own degradation products (Veuger et al. 2006, 2007a). Overall, once the macroalgal biomass is hydrolyzed to DOM, it is effectively shuttled back and forth between bacteria and BMA in organic and inorganic forms. This efficient recycling of ${ }^{13} \mathrm{C}$ and ${ }^{15} \mathrm{~N}$ has been observed in other studies (Middelburg et al. 2000, Veuger et al. 2007a). Numerous studies have shown BMA production to be limited when live macroalgae are present in dense accumulations, presumably due to light limitation at the sediment surface (Astill \& Lavery 2001, McGlathery et al. 2001, Hardison 2010). However, our results suggest that once the light limitation is relieved after macroalgae die, 5 to $9 \%$ of $\mathrm{C}$ and 6 to $50 \%$ of $\mathrm{N}$ originally present as macroalgal biomass is transferred to the sediments and

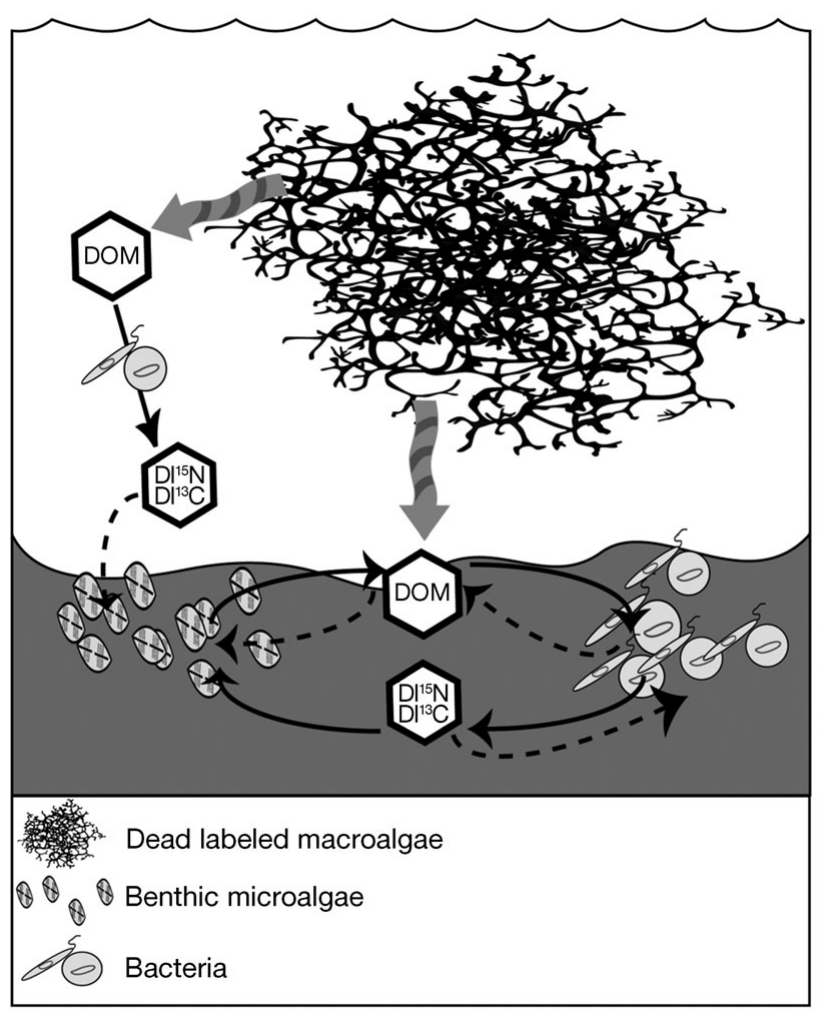

Fig. 6. Proposed mechanism for microbial processing of dead macroalgal biomass within the sediments. DIC(N): dissolved inorganic carbon (nitrogen); DOM: dissolved organic matter 
stored (temporarily) as microbial biomass. Even though macroalgal distributions may be patchy, the work of Franke et al. (2006) has shown that the effects of a macroalgal die-off may be expansive in the sediments of some systems. In their study, macroalgal DOM was distributed well beyond the deposition location in systems that experienced advective flow, fueling heterotrophic bacteria throughout the sediments.

\section{Summary and implications for eutrophied systems}

The extent to which sediments act as a sink for macroalgal $\mathrm{C}$ and $\mathrm{N}$ depends largely on the amount of biomass transferred to the sediments as well as recycling processes within the sediments. In our experiment, less than half of the macroalgae was incorporated into the sediments from HIB, and even less for sediments from IWB. The isolation of our mesocosms from the hydrodynamic regime typically found in the environment may have biased the amount of macroalgal biomass that was transferred to the sediments relative to what occurs in the environment. On the one hand, we may have overestimated transfer of macroalgal material to the sediments if wave and tidal action disperse the macroalgal detritus and decrease deposition onto the sediment surface. On the other hand, our estimate may have been conservative if hydrodynamic mixing of the sediment surface entrains macroalgae into the sediments. In either case, it is clear from other laboratory and field studies that some fraction of macroalgae associated with blooms is transferred to the sediments following die-off (Sfriso et al. 1992, Lomstein et al. 2006, García-Robledo et al. 2008). We suggest that further research investigating the influence of hydrodynamic forcings and sediment resuspension on macroalgal decomposition in the sediments is warranted. Nevertheless, the present study suggests that uptake and recycling of $\mathrm{C}$ and $\mathrm{N}$ by BMA and bacteria within the sediments may serve as a temporary reservoir for a fraction of the $\mathrm{C}$ and $\mathrm{N}$ that was previously stored as macroalgal biomass. While bacteria are the primary agents of macroalgae decomposition, BMA intercept the return of nutrients to the water column, thereby diminishing phytoplankton uptake and the positive feedback to further eutrophication.

Acknowledgements. This research was supported by the National Science Foundation (VCR-LTER project DEB 0080381 and DEB 0621014; DEB Ecosystems 0542645 to I.C.A. and E.A.C.), the European Association of Organic Geochemists (Shell Travel Award to A.K.H.), the Netherlands Organization for Scientific Research (B.V.), the Darwin Center for Biogeosciences (B.V.), and the Environmental Protec- tion Agency (STAR FP916722010 to A.K.H.). The EPA has not officially endorsed this publication and the views expressed herein may not reflect the views of the EPA. This work would not have been possible without the help of M. Luckenbach, S. Fate, and R. Bonniwell at the VIMS ESL; J. Stanhope, H. Walker, B. Neikirk, E. Lerberg, C. Funkey, P. Littreal, and R. Bushnell at VIMS; and J. Middelburg, M. Houtekamer and P. van Rijswijk at NIOO. This is VIMS contribution 3109 and NIOO contribution 4832.

\section{LITERATURE CITED}

Aberle N, Witte U (2003) Deep-sea macrofauna exposed to a simulated sedimentation event in the abyssal NE Atlantic: in situ pulse-chase experiments using ${ }^{13} \mathrm{C}$-labelled phytodetritus. Mar Ecol Prog Ser 251:37-47

Anderson IC, Stanhope JW, Hardison AK, McGlathery KJ (2010) Sources and fates of nitrogen in Virginia coastal bays. In: Kennish MJ, Paerl HW (eds) Coastal lagoons: critical habitats of environmental change. CRC Press, Boca Raton, FL, p 43-72

Arnosti C (2004) Speed bumps and barricades in the carbon cycle: substrate structural effects on carbon cycling. Mar Chem 92:263-273

Astill H, Lavery PS (2001) The dynamics of unattached benthic macroalgal accumulations in the Swan-Canning Estuary. Hydrol Process 15:2387-2399

Bintz JC, Nixon SW, Buckley BA, Granger SL (2003) Impacts of temperature and nutrients on coastal lagoon plant communities. Estuaries 26:765-776

> Bligh EG, Dyer WJ (1959) A rapid method of total lipid extraction and purification. Can J Biochem Physiol 37: 911-917

Boynton WR, Hagy JD, Murray L, Stokes C, Kemp WM (1996) A comparative analysis of eutrophication patterns in a temperate coastal lagoon. Estuaries 19:408-421

Brush MJ, Nixon SW (2003) Biomass layering and metabolism in mats of the macroalga Ulva lactuca L. Estuaries 26: 916-926

> Buchsbaum R, Valiela I, Swain T, Dzierzeski M, Allen S (1991) Available and refractory nitrogen in detritus of coastal vascular plants and macroalgae. Mar Ecol Prog Ser 72: 131-143

Canuel EA, Freeman KH, Wakeham SG (1995) Seasonal changes in the sources of organic matter delivered to a coastal sediment: a GC-IRMS approach. Abstr Pap Am Chem Soc 210:70

Canuel EA, Spivak AC, Waterson EJ, Duffy JE (2007) Biodiversity and food web structure influence short-term accumulation of sediment organic matter in an experimental seagrass system. Limnol Oceanogr 52:590-602

Castaldelli G, Welsh DT, Flachi G, Zucchini G, Colombo G, Rossi R, Fano EA (2003) Decomposition dynamics of the bloom forming macroalga Ulva rigida C. Agardh determined using a ${ }^{14} \mathrm{C}$-carbon radio-tracer technique. Aquat Bot 75:111-122

Cummins SP, Roberts DE, Zimmerman KD (2004) Effects of the green macroalga Enteromorpha intestinalis on macrobenthic and seagrass assemblages in a shallow coastal estuary. Mar Ecol Prog Ser 266:77-87

Dembitsky VM, Pechenkinashubina EE, Rozentsvet OA (1991) Glycolipids and fatty acids of some seaweeds and marine grasses from the Black Sea. Phytochemistry 30: 2279-2283

Deming JW, Baross JA (1993) The early diagenesis of organic matter: bacterial activity. In: Engel MH, Macko SA (eds) 
Organic geochemistry. Plenum Press, New York, NY, p $119-144$

Duarte CM (1995) Submerged aquatic vegetation in relation to different nutrient regimes. Ophelia 41:87-112

Ducklow H (2000) Bacterial production and biomass in the oceans. In: Kirchman DL (ed) Microbial ecology of the oceans. Wiley-Liss, New York, NY, p 85-120

Evrard V, Cook PLM, Veuger B, Huettel M, Middelburg JJ (2008) Tracing carbon and nitrogen incorporation and pathways in the microbial community of a photic subtidal sand. Aquat Microb Ecol 53:257-269

Franke U, Polerecky L, Precht E, Huettel M (2006) Wave tank study of particulate organic matter degradation in permeable sediments. Limnol Oceanogr 51:1084-1096

García-Robledo E, Corzo A, García de Lomas J, van Bergeijk SA (2008) Biogeochemical effects of macroalgal decomposition on intertidal microbenthos: a microcosm experiment. Mar Ecol Prog Ser 356:139-151

Giordano JP (2009) Nutrient loading and system response in the coastal lagoons of the Delmarva Peninsula. MSc thesis, College of William and Mary, Williamsburg, VA

Goldman JC, Dennett MR (2000) Growth of marine bacteria in batch and continuous culture under carbon and nitrogen limitation. Limnol Oceanogr 45:789-800

Gontang EA, Fenical W, Jensen PR (2007) Phylogenetic diversity of gram-positive bacteria cultured from marine sediments. Appl Environ Microbiol 73:3272-3282

Gordon DM, McComb AJ (1989) Growth and production of the green alga Cladophora montagneana in a eutrophic Australian estuary and its interpretation using a computer program. Water Res 23:633-645

Goshorn D, McGinty M, Kennedy C, Jordan C, Wazniak C, Schwenke K, Coyne K (2001) An examination of benthic macroalgae communities as indicators of nutrients in middle Atlantic coastal estuaries: Maryland component. Final Report 1998-1999. Maryland Department of Natural Resources, Annapolis, MD

Hardison AK (2010) Interactions between macroalgae and the sediment microbial community: nutrient cycling within shallow coastal bays. PhD dissertation, College of William and Mary, Williamsburg, VA, p 121-174

Hauxwell J, Cebrian J, Furlong C, Valiela I (2001) Macroalgal canopies contribute to eelgrass (Zostera marina) decline in temperate estuarine ecosystems. Ecology 82:1007-1022

> Hedges JI, Stern JH (1984) Carbon and nitrogen determinations of carbonate-containing solids. Limnol Oceanogr 29: 657-663

> Higgins SN, Hecky RE, Guildford SJ (2008) The collapse of benthic macroalgal blooms in response to self-shading. Freshw Biol 53:2557-2572

Holmquist JG (1997) Disturbance and gap formation in a marine benthic mosaic: influence of shifting macroalgal patches on seagrass structure and mobile invertebrates. Mar Ecol Prog Ser 158:121-130

Howarth RW, Marino R (2006) Nitrogen as the limiting nutrient for eutrophication in coastal marine ecosystems: evolving views over three decades. Limnol Oceanogr 51: 364-376

Kenward MG (1987) A method for comparing profiles of repeated measurements. Appl Stat 36:296-308

Khotimchenko SV (2005) Lipids from the marine alga Gracilaria verrucosa. Chem Nat Compd 41:285-288

Kirchman DL (2000) Uptake and regeneration of inorganic nutrients by marine heterotrophic bacteria. In: Kirchman DL (ed) Microbial ecology of the oceans. Wiley-Liss, New York, NY, p 261-288

Lomstein BA, Guldberg LB, Neubauer ATA, Hansen J and others (2006) Benthic decomposition of Ulva lactuca: a controlled laboratory experiment. Aquat Bot 85:271-281

Lorenzen CJ (1967) Determination of chlorophyll and pheo-pigments: spectrophotometric equations. Limnol Oceanogr 12: 343-346

McGlathery KJ, Pedersen MF, Borum J (1996) Changes in intracellular nitrogen pools and feedback controls on nitrogen uptake in Chaetomorpha linum (Chlorophyta). J Phycol 32:393-401

McGlathery KJ, Krause-Jensen D, Rysgaard S, Christensen PB (1997) Patterns of ammonium uptake within dense mats of the filamentous macroalga Chaetomorpha linum. Aquat Bot 59:99-115

McGlathery KJ, Anderson IC, Tyler AC (2001) Magnitude and variability of benthic and pelagic metabolism in a temperate coastal lagoon. Mar Ecol Prog Ser 216:1-15

McGlathery KJ, Sundbäck K, Anderson IC (2007) Eutrophication in shallow coastal bays and lagoons: the role of plants in the coastal filter. Mar Ecol Prog Ser 348:1-18

> Middelburg JJ, Barranguet C, Boschker HTS, Herman PMJ, Moens T, Heip CHR (2000) The fate of intertidal microphytobenthos carbon: an in situ ${ }^{13} \mathrm{C}$-labeling study. Limnol Oceanogr 45:1224-1234

Moodley L, Boschker HTS, Middelburg JJ, Pel R, Herman PMJ, de Deckere E, Heip CHR (2000) Ecological significance of benthic foraminifera: ${ }^{13} \mathrm{C}$ labelling experiments. Mar Ecol Prog Ser 202:289-295

Morand P, Briand X (1996) Excessive growth of macroalgae: a symptom of environmental disturbance. Bot Mar 39: 491-516

> Moriarty DJW, Hayward AC (1982) Ultrastructure of bacteria and the proportion of Gram-negative bacteria in marine sediments. Microb Ecol 8:1-14

Nedergaard RI, Risgaard-Petersen N, Finster K (2002) The importance of sulfate reduction associated with Ulva lactuca thalli during decomposition: a mesocosm approach. J Exp Mar Biol Ecol 275:15-29

Nilsson C, Sundback K (1996) Amino acid uptake in natural microphytobenthic assemblages studied by microautoradiography. Hydrobiologia 332:119-129

> Nuzzi R, Waters RM (2004) Long-term perspective on the dynamics of brown tide blooms in Long Island coastal bays. Harmful Algae 3:279-293

Oertel GF (2001) Hypsographic, hydro-hypsographic and hydrological analysis of coastal bay environments, Great Machipongo Bay, Virginia. J Coast Res 17:775-783

Parkes RJ (1987) Analysis of microbial communities within sediments using biomarkers. In: Hetcher M, Gray RTG, Jones JG (eds) Ecology of microbial communities. Cambridge University Press, Cambridge, p 147-177

Pavoni B, Marcomini A, Sfriso A, Donazzolo R, Orio AA (1992) Changes in an estuarine ecosystem: the lagoon of Venice as a case study. ACS Symp Ser 483:287-305

> Peckol P, Rivers JS (1995) Physiological responses of the opportunistic macroalgae Cladophora vagabunda (L) Vandenhoek and Gracilaria tikvahiae (Mclachlan) to environmental disturbances associated with eutrophication. J Exp Mar Biol Ecol 190:1-16

Pedersen MF, Nielsen SL, Banta GT (2004) Interactions between vegetation and nutrient dynamics in coastal marine ecosystems: an introduction. In: Nielsen SL, Banta GT, Pedersen MF (eds) Estuarine nutrient cycling: the influence of primary producers. Kluwer Academic Publishers, Dordrecht, p 1-16

Perry GJ, Volkman JK, Johns RB, Bavor HJ (1979) Fatty acids of bacterial origin in contemporary marine sediments. Geochim Cosmochim Acta 43:1715-1725 
Pinckney J, Papa R, Zingmark R (1994) Comparison of highperformance liquid-chromatographic, spectrophotometric, and fluorometric methods for determining chlorophyll a concentrations in estuarine sediments. J Microbiol Methods 19:59-66

Poerschmann J, Carlson R (2006) New fractionation scheme for lipid classes based on 'in-cell fractionation' using sequential pressurized liquid extraction. J Chromatogr A 1127:18-25

Raffaelli D (2000) Interactions between macro-algal mats and invertebrates in the Ythan estuary, Aberdeenshire, Scotland. Helgol Mar Res 54:71-79

Rossi F (2007) Recycle of buried macroalgal detritus in sediments: use of dual-labelling experiments in the field. Mar Biol 150:1073-1081

Schmidt JL, Deming JW, Jumars PA, Keil RG (1998) Constancy of bacterial abundance in surficial marine sediments. Limnol Oceanogr 43:976-982

Sfriso A, Marcomini A (1999) Macrophyte production in a shallow coastal lagoon. Part II: coupling with sediment, SPM and tissue carbon, nitrogen and phosphorus concentrations. Mar Environ Res 47:285-309

Sfriso A, Pavoni B, Marcomini A, Raccanelli S, Orio AA (1992) Particulate matter deposition and nutrient fluxes onto the sediments of the Venice lagoon. Environ Technol 13: 473-483

Smith DJ, Underwood GJC (1998) Exopolymer production by intertidal epipelic diatoms. Limnol Oceanogr 43: 1578-1591

Stanhope JW, Anderson IC, Reay WG (2009) Base flow nutrient discharges from lower Delmarva Peninsula watersheds of Virginia. J Environ Qual 38:2070-2083

Thomsen MS, Gurgel CFD, Fredericq S, McGlathery KJ (2006) Gracilaria vermiculophylla (Rhodophyta, Gracilariales) in Hog Island Bay, Virginia: a cryptic alien and invasive macroalga and taxonomic correction. J Phycol 42: 139-141

Thybo-Christesen M, Rasmussen MB, Blackburn TH (1993) Nutrient fluxes and growth of Cladophora sericea in a shallow Danish bay. Mar Ecol Prog Ser 100:273-281

Tyler AC, McGlathery KJ (2006) Uptake and release of nitrogen by the macroalgae Gracilaria vermiculophylla (Rhodophyta). J Phycol 42:515-525

Editorial responsibility: Just Cebrian,

Dauphin Island, Alabama, USA
Tyler AC, McGlathery KJ, Anderson IC (2001) Macroalgae mediation of dissolved organic nitrogen fluxes in a temperate coastal lagoon. Estuar Coast Shelf Sci 53:155-168

Underwood GJC, Kromkamp J (1999) Primary production by phytoplankton and microphytobenthos in estuaries. Adv Ecol Res 29:93-153

Valiela I, Foreman K, Lamontagne M, Hersh D and others (1992) Couplings of watersheds and coastal waters: sources and consequences of nutrient enrichment in Waquoit Bay, Massachusetts. Estuaries 15:443-457

> Valiela I, McClelland J, Hauxwell J, Behr PJ, Hersh D, Foreman K (1997) Macroalgal blooms in shallow estuaries: controls and ecophysiological and ecosystem consequences. Limnol Oceanogr 42:1105-1118

Veuger B, Middelburg JJ, Boschker HTS, Houtekamer M (2005) Analysis of ${ }^{15} \mathrm{~N}$ incorporation into D-alanine: a new method for tracing nitrogen uptake by bacteria. Limnol Oceanogr Methods 3:230-240

- Veuger B, van Oevelen D, Boschker HTS, Middelburg JJ (2006) Fate of peptidoglycan in an intertidal sediment: an in situ 13C-labeling study. Limnol Oceanogr 51: 1572-1580

Veuger B, Eyre BD, Maher D, Middelburg JJ (2007a) Nitrogen incorporation and retention by bacteria, algae, and fauna in a subtropical intertidal sediment: an in situ ${ }^{15} \mathrm{~N}$ labeling study. Limnol Oceanogr 52:1930-1942

Veuger B, Middelburg JJ, Boschker HTS, Houtekamer M (2007b) Update of 'Analysis of ${ }^{15} \mathrm{~N}$ incorporation into Dalanine: a new method for tracing nitrogen uptake by bacteria' (Veuger et al. 2005, Limnol Oceanogr Methods 3: 30-240). Limnol Oceanogr Methods 5:192-194

> Volkman JK, Barrett SM, Blackburn SI, Mansour MP, Sikes EL, Gelin F (1998) Microalgal biomarkers: a review of recent research developments. Org Geochem 29: 1163-1179

Wakeham SG, Canuel EA (2006) Degradation and preservation of organic matter in marine sediments. In: Volkman JK (ed) Handbook of environmental chemistry, Vol 2, Part N. Springer-Verlag, Berlin, p 295-321

Witte U, Aberle N, Sand M, Wenzhöfer F (2003) Rapid response of a deep-sea benthic community to POM enrichment: an in situ experimental study. Mar Ecol Prog Ser 251:27-36

Submitted: October 16, 2009; Accepted: June 29, 2010

Proofs received from author(s): August 26, 2010 